San Jose State University

SJSU ScholarWorks

Faculty Publications, Biological Sciences

Biological Sciences

January 2015

\title{
Warm Microhabitats Drive Both Increased Respiration and Growth Rates of Intertidal Consumers
}

\author{
Luke P. Miller \\ Stanford University, luke.miller@sjsu.edu \\ Bengt J. Allen \\ California State University - Long Beach \\ Felicia A. King \\ Stanford University \\ Daisy R. Chilin \\ California State University - Long Beach \\ Vanessa M. Reynoso \\ California State University - Long Beach
}

See next page for additional authors

Follow this and additional works at: https://scholarworks.sjsu.edu/biol_pub

Part of the Biology Commons

\begin{abstract}
Recommended Citation
Luke P. Miller, Bengt J. Allen, Felicia A. King, Daisy R. Chilin, Vanessa M. Reynoso, and Mark W. Denny. "Warm Microhabitats Drive Both Increased Respiration and Growth Rates of Intertidal Consumers" Marine Ecology Progress Series (2015): 127-143.
\end{abstract}

This Article is brought to you for free and open access by the Biological Sciences at SJSU ScholarWorks. It has been accepted for inclusion in Faculty Publications, Biological Sciences by an authorized administrator of SJSU ScholarWorks. For more information, please contact scholarworks@sjsu.edu. 


\section{Authors}

Luke P. Miller, Bengt J. Allen, Felicia A. King, Daisy R. Chilin, Vanessa M. Reynoso, and Mark W. Denny 
1 Warm microhabitats drive both increased respiration and growth rates of intertidal consumers

4 Luke P. Miller ${ }^{1, *}$, Bengt J. Allen ${ }^{2}$, Felicia A. King ${ }^{1}$, Daisy R. Chilin ${ }^{2}$, Vanessa M. Reynoso ${ }^{2}$, Mark W. Denny ${ }^{1}$

$6{ }^{1}$ Hopkins Marine Station, Stanford University, Pacific Grove, CA, USA 93950

$7{ }^{2}$ Department of Biological Sciences, California State University Long Beach, Long Beach, CA, $8 \quad$ USA 90840

$9 *$ corresponding author: contact@lukemiller.org

10 Running headline: Intertidal limpet respiration and growth

\section{Abstract}

12 Rocky intertidal organisms are often exposed to broadly fluctuating temperatures as the tides rise

13 and fall. Many mobile consumers living on the shore are immobile during low tide, and can be

14 exposed to high temperatures on calm, warm days. Rising body temperatures can raise metabolic

15 rates, induce stress responses, and potentially affect growth and survival, but the effects may

16 differ among species with different microhabitat preferences. We measured aerial and aquatic

17 respiration rates of four species of Lottia limpets from central California, and estimated critical

18 thermal maxima. In a variety of microhabitats in the field we tracked body temperatures and

19 measured limpet growth rates on experimental plates colonized with natural microalgae. Limpet 
20 species found higher on the shore had lower peak respiration rates during high temperature aerial

21 exposure, and had higher critical thermal maxima. Using our long-term records of field body

22 temperatures, we estimated cumulative respiration to be 5 to $14 \%$ higher in warm microhabitats.

23 Growth rates in the field were driven by an interaction between available microalgal food

24 resources, low tide temperature, and limpet species identity, with limpets from warmer

25 microhabitats responding positively to higher food availability and higher low tide temperatures.

26 Stressful conditions in warm microhabitats make up a small portion of the total lifetime of these

27 limpets, but the greater proportion of time spent at non-stressful, but warm, body temperatures

28 may enhance growth compared to limpets living in cooler microhabitats.

29 Keywords: intertidal zone, limpet, microalgae, shore height, temperature stress, thermotolerance

\section{Introduction}

31 Climate change research in a variety of aquatic systems has pointed to the potential for

32 mildly increasing water temperatures to increase ectotherms' metabolic and foraging rates, and

33 to increase the impacts of top-down control by consumers on resources (O'Connor 2009,

34 O’Connor et al. 2009, Hoekman 2010, Kratina et al. 2012, O’Regan et al. 2014). As waters

35 warm, the increasing speed of fundamental chemical reactions at the cellular level leads to

36 increasing energy usage for maintenance metabolism and growth (Hochachka \& Somero 2002)

37 that must typically be balanced by increasing the rate of consumption, which in some cases can

38 strengthen trophic cascades (Kratina et al. 2012). Provided there is room for acclimatization to a

39 warmer temperature regime (Stillman 2003, Deutsch et al. 2008, Tewksbury et al. 2008), the rate

40 of energy flow up through the trophic levels of the system could increase as species living below

41 their optimum performance temperature move up the rising slope of their respective temperature 
42 performance curves (Fig. 1A; Huey \& Stevenson 1979), potentially driving greater productivity

43 (Angilletta et al. 2010).

44 In the rocky intertidal zone, the effects of benign water temperature fluctuations as

45 seawater warms and cools during high tide have been pointed to as potential benefits for some

46 intertidal consumers. Sanford and collaborators have shown that foraging rate increases within a

47 limited range of increasing water temperature for key intertidal species, including the keystone

48 predator Pisaster ochraceus, which increases its per capita predation on intertidal mussels that

49 are often the dominant competitors for space in the mid intertidal zone (Sanford 1999, Sanford \&

50 Menge 2001, Sanford 2002, Pincebourde et al. 2008). Warmer waters can also increase intertidal

51 mussel growth (Phillips 2005, Kroeker et al. 2014) and speed up feeding rates in predatory snails

52 (Largen 1967, Bayne \& Scullard 1978, Yamane \& Gilman 2009, Miller 2013). However, those

53 are the rare cases for which we know where on the thermal performance curve an intertidal

54 organism sits relative to the range of varying temperatures experienced in its habitat. For other

55 organisms it is difficult to predict when or how often rising body temperatures could move the

56 organism from the ascending slope of the curve, past its optimum temperature, and onto the

57 descending slope. The distribution of temperatures experienced by intertidal organisms is

58 dominated by the influence of water temperature at high tide, while aerial exposure during low

59 tide can bring swings to either colder or warmer temperatures, as shown for high-intertidal-zone

60 limpets from Monterey Bay, California (Figure 1B). Most of these temperature fluctuations are

61 mild enough to avoid temperature stress (hatched region, Figure $1 \mathrm{~B}$, with the $28{ }^{\circ} \mathrm{C}$ upper limit

62 based on heat shock protein expression data from Dong et al. 2008), but occasional hot weather

63 conditions can drive body temperatures to extremes (gray region, Figure 1B), when low tides

64 leave marine organisms high and dry for hours at a time (Helmuth 1999, Denny \& Harley 2006, 
65 Denny et al. 2009). The temporal coincidence of warm water and air temperatures may also have

66 complicated interacting effects. Periods of cooler water temperatures at high tide have the

67 potential to offset negative effects of warm low tide conditions by providing time to recover

68 from stress, but periods with warm low tides and warm high tides occurring out of phase by

69 several days could have strong negative effects by leaving little time to recover (Pincebourde et

70 al. 2012).

Much of the climate-change related research in intertidal systems has focused on the

72 negative effects of increasing temperature, particularly on extreme aerial temperatures that

73 induce heat stress and occasionally cause mortality events during low tide (Tomanek \& Somero

74 1999, Stillman 2002, Tomanek 2002, Muñoz et al. 2005, Jones et al. 2009, Miller et al. 2009,

75 Tomanek \& Zuzow 2010, Miller et al. 2014). The assumption is often that low tide conditions,

76 when animals and algae are exposed to air, can drive species past their optimal temperature range

77 and down the descending slope of the temperature performance curve, with negative energetic

78 consequences derived from limited oxygen delivery or organ failure (Pörtner 2012) and the need

79 to shunt energy into heat shock responses to recover from high temperature insults (Feder \&

80 Hofmann 1999). In addition, due to the physiological need for available water, most algal

81 photosynthesis and animal feeding occurs at high tide when body temperatures are at equilibrium

82 with the cool ocean. As the tide drops and the rocks dry, photosynthesis slows (Hunt \& Denny

83 2008) and nearly all feeding activity comes to a stop (Craig 1968, Eaton 1968, Miller 1968). As a

84 result, the potential benefits of a warming body and faster metabolism that can occur in fully

85 aquatic systems are decoupled from the opportunity to feed or photosynthesize for the many

86 sessile, or functionally-sessile, organisms in the intertidal zone during low tide. 
The cessation of feeding does not necessarily mark the end of energy acquisition, since

88 digestion of a meal may take hours, and those hours may include warm daytime low tide

89 conditions. In aquatic habitats, when food is abundant, the temperature for optimal growth in

90 ectotherms can increase (Elliott 1976, Elliott 1982, Stich \& Lampert 1984, Pangle \& Peacor

91 2010), and warmer temperatures can increase the rate of digestion (Brett \& Higgs 1970,

92 Diefenbach 1975, Bayne \& Scullard 1978). However, in the intertidal zone where food

93 availability or foraging time may be restricted, the scope for growth will be lower and there can

94 be an expanded range of high temperatures where metabolic maintenance costs outstrip energy

95 intake (Woodin et al. 2013, Iles 2014). Therefore, along the seashore, it remains an open

96 question as to whether warm, dry conditions during daytime low tides are a potential benefit or

97 simply a cost for consumers and their algal resources, though some studies show that the effects

98 of warm temperatures at low tide need not be solely negative (Gilman 2006, Blanchette et al.

99 2007).

100 We address this question using limpets in the genus Lottia found on the central coast of

101 California. In rocky intertidal zones around the world, limpets represent an important class of

102 herbivorous grazers that can structure the intertidal community by selectively removing algae

103 and settling invertebrates (Jones 1948, Branch 1981, Hawkins \& Hartnoll 1983). Limpets forage

104 while the rocks are awash during rising and falling high tides, and typically remain fixed in place

105 on the rock during low tide when the sea recedes (though some tropical species move with the

106 tides, Williams \& Morritt 1995). This foraging pattern often precludes any sort of shelter-seeking

107 behavior when low tide environmental conditions might generate temperature and desiccation

108 stress. Unlike more mobile species that could shuttle between different thermal microhabitats to

109 control body temperature near some optimum performance peak (Huey 1991, Hertz et al. 1993, 
110 Allen \& Levinton 2014), limpets are functionally sessile at low tide and their body temperatures

111 can exceed the optimum temperature range, in some cases inducing sublethal or lethal stress

112 (Dong et al. 2008). While the rock is dry there is no opportunity to graze microalgae, but there is

113 some indication that digestion may continue during low tide periods (Walker 1968; L. Miller

114 personal observation). Limpets are ideal for studies of temperature effects, as their large foot

115 keeps them tightly thermally coupled to the underlying substratum, so that temperature

116 measurements of the substratum can act as accurate proxies for limpet body temperature without

117 disturbing the organism (Wolcott 1973, Denny \& Harley 2006).

The four Lottia species utilized in this study differ in their preferred shore height and

119 microhabitat (Figure 2). The vertical distributions of the four species overlap to some extent, but

120 they are often found in distinct microhabitats. L. pelta Rathke and L. limatula Carpenter are

121 found in the low and mid intertidal zone, with L. pelta favoring wave-exposed walls or mussel

122 beds where it consumes both microalgae and macroalgae, while L. limatula is often found on

123 more sun-exposed horizontal surfaces and feeds primarily on microalgae (Craig 1968, Eaton

124 1968, Wolcott 1973). L. scabra Gould and L. austrodigitalis Murphy are found higher on the

125 shore, above the Mytilus californianus mussel zone and often above the limits of the Endocladia

126 muricata macroalgal zone (Wolcott 1973). Both high-zone species are found on vertical walls,

127 but L. scabra is also found on horizontal, sun-exposed rocks where L. austrodigitalis is often

128 absent (Collins 1976, Hahn \& Denny 1989). L. austrodigitalis is the highest ranging limpet on

129 the central California coast, often found more than five meters above Mean Lower Low Water

130 (MLLW) on wave-exposed rock walls (Miller 1968) in a region where the maximal still-water

131 tidal range is approximately $2.5 \mathrm{~m}$. 
In Monterey Bay, L. austrodigitalis overlaps with a cryptic congener, L. digitalis Rathke,

133 which can only reliably be distinguished via genetic methods, but the two species share similar

134 behaviors and occupy the same microhabitats (Murphy 1978, Crummett \& Eernisse 2007).

135 Recent work at our field site at Hopkins Marine Station (HMS hereafter, Pacific Grove, CA,

$13636.6217 \mathrm{~N} 121.9043 \mathrm{~W}$ ) has shown that L. austrodigitalis makes up the majority (88-89\%) of the

137 population of the cryptic species pair living on high shore rock habitats where we sampled (Dong

138 et al. 2008, Dong \& Somero 2009). This work also indicates that the two species overlap in their

139 median upper thermal tolerance limits, with L. austrodigitalis being marginally more tolerant and

140 producing more thermally stable cytosolic malate dehydrogenase (Dong \& Somero 2009). We

141 refer to L. austrodigitalis hereafter in this study while acknowledging that a small fraction of our

142 samples may include L. digitalis.

143 To explore the potential effects of sub-lethal temperature variation on intertidal limpets,

144 we measured respiration rate across a range of temperatures under aquatic and aerial conditions

145 in the laboratory and tracked growth in the field while measuring microhabitat temperature and

146 microalgal food supply. We looked for evidence of physiological compensation for increasing

147 temperatures via reductions in the $\mathrm{Q}_{10}$ response of respiration $\left(\mathrm{Q}_{10}\right.$ is defined as the ratio of the

148 rates of a physiological or biochemical process over a $10{ }^{\circ} \mathrm{C}$ rise in temperature, where the

149 common expectation is for a doubling of the rate, $\mathrm{Q}_{10}=2$, Hochachka \& Somero 2002), and

150 measured upper critical thermal maxima during aerial exposure. We expected to find increasing

151 respiration rates with increasing body temperatures, such that field microhabitats with warmer

152 low tide temperatures could either yield reduced limpet growth due to greater energetic demands,

153 or increased growth if sufficient food was available to support higher metabolic rates. We 
154 hypothesized that high shore and low shore limpets would differ in their response to warmer low 155 tide temperatures, with high shore species being better adapted to cope with higher temperatures.

156 Methods

157 Collections

158 We collected the four species of limpets: L. scabra, L. austrodigitalis, L. limatula, and $L$. 159 pelta, from south- and east-facing rocks at HMS during September and October 2013. The

160 individuals collected for the trials were representative of the range of sizes of sub-adult and small

161 adult limpets found at HMS for each of the four species (Table S1). Batches of limpets were

162 collected and held in a shaded seawater table for 2 to 7 days prior to use in the respiration trials.

163 Temperature in the seawater table was monitored with an iButton temperature logger (DS1921G,

164 Maxim Integrated, San Jose, CA, USA) and remained at $15^{\circ} \mathrm{C}$ during the experimental period.

\section{Respiration trials}

166 The respiration chamber consisted of a custom-machined aluminum block with 15 wells

167 of $15 \mathrm{ml}$ volume each, and a bolt-on top plate that contained ports for purging the chambers and

168 making oxygen measurements. The block was submerged in a digitally-controlled water bath to

169 maintain temperatures during trials. Oxygen measurements were taken using ruthenium sensor

170 dots adhered to a glass port in the top plate for each well (aerial trials: RedEye patch, Ocean

171 Optics, Dunedin, FL, USA; aquatic trials: SP-PSt3-NAU-D5-YOP, PreSens Precision Sensing

$172 \mathrm{GmbH}$, Regensburg, Germany) and read with a fiber-optic fluorescence-based optode system

173 (NeoFox, Ocean Optics). The chamber top plate contained machined recesses and an indexing

174 pin to ensure that the optode was placed at the same height and incident angle relative to the

175 sensor patch for every reading, since deviations in positioning will substantially alter the signal 
176 produced by the optode measuring system. Each oxygen sensor dot was recalibrated following

177 each replicate trial using water-saturated normoxic air and pure $\mathrm{CO}_{2}$ at the corresponding

178 experimental temperature to make a two point calibration.

Aerial respiration

180 For aerial respiration trials, we reduced the volume of each chamber to $5 \mathrm{ml}$ by inserting

181 a $10 \mathrm{ml}$ aluminum plug in the bottom of each well. 12 limpets, three per species, were run in

182 individual wells along with three empty (blank) wells for each replicate trial. Each well also

183 contained a $5 \mathrm{~mm}$ diameter piece of paper towel wetted with seawater to maintain $100 \%$ relative

184 humidity during the trial. The aluminum block was initially held at $15^{\circ} \mathrm{C}$ for $20 \mathrm{~min}$, and the

185 temperature of the water bath and block was then raised or lowered at a rate of $10^{\circ} \mathrm{C} \mathrm{h}^{-1}$ to the

186 target experimental temperature for each trial. A total of 9 experimental temperatures were used

187 in the aerial trials: $10,15,20,25,30,32.5,35,37.5$, and $40{ }^{\circ} \mathrm{C}$. The time during the ramp to

188 lower and higher temperatures allowed limpets to acclimate to the chamber, while for trial

189 temperatures of $15{ }^{\circ} \mathrm{C}$ we waited 30 min before beginning the measurement process (equivalent

190 to the minimum acclimation period for the 10 and $20^{\circ} \mathrm{C}$ trials). The top plate of the chambers

191 was bolted on and ports sealed to begin a $2 \mathrm{~h}$ measurement period. During the sampling period,

192 the fiber optic sensor for the optode system was moved to each chamber well in succession for a

$19315 \mathrm{~s}$ reading, and each well was sampled every $8 \mathrm{~min}$. The $2 \mathrm{~h}$ exposure allowed sufficient time

194 for limpets to deplete a measurable amount of oxygen even at the lowest temperatures.

195 Aquatic respiration

196 The full $15 \mathrm{ml}$ volume of the respiration chamber wells was used for the aquatic trials.

197 We used artificial seawater (Instant Ocean, Blacksburg, VA, USA) mixed to a practical salinity

198 of 33 to fill each chamber. Seawater was equilibrated to $15{ }^{\circ} \mathrm{C}$ and aerated before filling the 
199 chambers. As in the aerial respiration trials, a single limpet was placed in each well, with three 200 representatives of each of the four species filling 12 of the chamber wells, along with three

201 empty (blank) wells. Aquatic temperature trials took place at $10,12.5,15$, and $17.5^{\circ} \mathrm{C}$, to cover

202 the range of typical seawater temperatures found through the year at HMS. The temperature of 203 the chambers was changed at $10{ }^{\circ} \mathrm{C} \mathrm{h}^{-1}$, and a minimum acclimation period of 30 min was given

204 for trials that took less than 30 min to reach the experimental target temperature $(12.5,15$, and

$20517.5^{\circ} \mathrm{C}$ trials). We used the $10{ }^{\circ} \mathrm{C} \mathrm{h}^{-1}$ rate of water temperature change to harmonize our trial run

206 times with those of the aerial respiration trials, and although our largest shift in water

207 temperature did not exceed $5^{\circ} \mathrm{C}$, it should be noted that this rate of water temperature change is

208 faster than the rate of natural water temperature shifts at this field site. Immediately prior to

209 closing the chambers, we flushed each chamber with aerated seawater, pre-equilibrated to the

210 experimental temperature. Prior to taking a reading in each chamber, the water was stirred

211 manually for $20 \mathrm{~s}$ with a stir rod mounted in one of the top ports. Readings were taken for $15 \mathrm{~s}$,

212 and each chamber was sampled every $8 \mathrm{~min}$ for $1 \mathrm{~h}$. We chose this shorter trial time to avoid

213 limpets depleting oxygen in the water.

\section{Processing respiration data}

215 Immediately following a respiration trial, we weighed each limpet to the nearest $0.1 \mathrm{mg}$,

216 in air and submerged in seawater. The displaced mass of the live limpet in seawater was used to

217 calculate the volume that the limpet occupied in a chamber well. The volume of air or seawater

218 in the chamber (minus the volume of the limpet) was used to calculate the volume of oxygen

219 present at each time point. For aquatic trials, the concentration of $\mathrm{O}_{2}$ in seawater $\left(\mathrm{mg}^{-1}\right)$ was

220 calculated using the temperature and salinity values for the trial with the relationship from

221 Benson and Krause (1984), and converted to $\mu$ mol of $\mathrm{O}_{2}$ using the volume of seawater in the 
222 chamber. We fit a linear regression to the $\mu$ mol of $\mathrm{O}_{2}$ through time to estimate the $\mathrm{O}_{2}$

223 consumption rate. The values from the blank control chambers were averaged and used to correct

224 for any drift that occurred during a trial. We dissected the tissue from the shell of each limpet

225 and dried it in a drying oven at $60{ }^{\circ} \mathrm{C}$ for $48 \mathrm{~h}$. The dry tissue mass was used to calculate the

226 mass-specific oxygen consumption rate for each limpet. Each limpet was used in only a single

227 temperature trial, and a total of 12 replicate limpets were used at each of the experimental

228 temperatures for each species. We estimated Arrhenius break temperatures for log-transformed

229 respiration rate with a piecewise regression using the R package segmented (Muggeo 2008).

230 We calculated $\mathrm{Q}_{10}$ values for aerial respiration rate across each successive pair of

231 temperatures in the experiment using the equation

$232 Q_{10}=\left(\frac{\text { Rate }_{2}}{\text { Rate }_{1}}\right)^{\frac{10}{\text { Temp }_{2}-\text { Temp }} 1}$.

233 To calculate $95 \%$ confidence intervals on this estimate, we used a bootstrap resampling

234 procedure on each pair of 12 respiration values at two temperatures to produce a distribution of

235 log-transformed $\mathrm{Q}_{10}$ estimates that better accounts for potential skew in the calculated values

236 than a standard error estimate based on the assumption of normality (Davison \& Hinkley 1997).

237 Heat coma temperatures in air

238 At the conclusion of each aerial respiration trial, we probed each limpet to determine if it

239 was still adhered to the chamber wall. Any limpet that was poorly adhered and had also retracted

240 the mantle tissue back from the edge of the shell was judged to be in heat coma. We fit a logit-

241 link binomial generalized linear model to calculate the median heat coma temperature, termed

242 the Critical Thermal Maximum, $\mathrm{CT}_{\max }$, for each species after $2 \mathrm{~h}$ at the experimental

243 temperature. 
245 In June 2013, we deployed a series of experimental plates in the rocky intertidal zone at

246 HMS to track limpet growth in various thermal microhabitats. Each plate was made of

247 aluminum, $10 \mathrm{~cm}$ diameter and $12 \mathrm{~mm}$ thick, topped with a layer of light gray rubber grip tape

248 (Safety Walk Tape, 3M, St. Paul, MN, USA). A $20 \mathrm{~mm}$ tall stainless steel mesh fence with 5.5

249 mm square openings was attached around the outer perimeter of the plate to dissuade limpets

250 from crawling off the plate. We machined a pocket into the underside of each aluminum plate to

251 hold an individually calibrated, wax-coated, iButton temperature datalogger with a resolution of

$2520.5^{\circ} \mathrm{C}(\mathrm{DS} 1921 \mathrm{G}$, Maxim Integrated, San Jose, CA, USA). The high thermal conductivity of

253 aluminum, the close proximity of the iButton to the upper surface of the plate, and the high

254 conductive heat exchange between the substratum and the large foot of a limpet allowed us to

255 use the iButton temperature as a direct proxy for the body temperature of the limpets attached to

256 the plate without disturbing the organisms (Wolcott 1973, Denny \& Harley 2006). The iButtons

257 recorded temperatures in each plate every 12 minutes; we downloaded the data every two weeks.

258 We attached the experimental plates to the granite bedrock at HMS using a single bolt

259 through the center of the plate, and ensured good thermal contact with the underlying rock by

260 installing a thin layer of concrete between the plate and rock surface to fill surface irregularities.

261 Each plate held four individuals from one of the four species of Lottia described above, and we

262 deployed additional plates without limpets to serve as grazer exclusion controls. The resulting

263 density of 0.5 limpets $\mathrm{cm}^{-2}$ is similar to values measured for natural high shore L. scabra

264 populations and lower than densities of limpet populations lower on the shore (Sutherland 1970,

265 Morelissen \& Harley 2007). A total of twelve plates per species (48 plates with limpets +12

266 grazer exclusion plates) were placed on sloped or vertical surfaces at 1.4 or $1.7 \mathrm{~m}$ above Mean 
267 Lower Low Water in horizontal transects at six sites. The sites included wave-exposed and 268 wave-protected microhabitats that faced predominantly north, east, or west, encompassing much

269 of the variety in microhabitats occupied by these species at HMS. The limpets were collected

270 from surrounding rocks and individually tagged with numbered bee tags (The Bee Works,

271 Orillia, ON, Canada) and cyanoacrylate glue. When limpets were lost from plates during the

272 experiment, they were replaced to keep the total number of limpets on each plate at four. Missing

273 limpets typically crawled over the fences and re-established on the surrounding rock face, and

274 the different species showed difference propensities for escaping, with an average of $0.11 \pm 0.15$

275 (1 SD) L. scabra, $0.70 \pm 0.42$ L. limatula, $1.12 \pm 0.85$ L. pelta, and $1.31 \pm 0.94$ L. austrodigitalis

276 limpets leaving per plate per census period. It should be noted that L. scabra typically establishes

277 a home "scar" and grows the margin of the shell to fit the contours of the rock (Wolcott 1973).

278 That tight fit was lost when we placed L. scabra on our plates, and it is possible that this may

279 have affected desiccation rates and energy expenditures initially. We observed that L. scabra

280 quickly established new home scars on the plates, and new shell growth matched the margins of

281 the shell to the flatter surface of the experimental plate by the next census date.

282 Following the initial deployment on June 17, the limpets on each plate were censused on

283 July 10, August 6, September 6, October 6, November 6, and December 1, 2013 as tide cycles

284 and wave conditions allowed. We tracked limpet growth using digital photographs taken from

285 overhead on each plate with a framer designed to keep a constant height and orientation to the

286 plate, so that we could measure the projected area of each limpet shell to $0.1 \mathrm{~mm}^{2}$ using ImageJ

287 (Rasband).

288 We used a PAM fluorometer (Diving-PAM, Walz GmbH, Effeltrich, Germany) to track 289 microalgal densities on the experimental plates. Microalgae were allowed to settle naturally from 
290 the ocean for one month prior to the start of data collection. During night time low tides

291 associated with each limpet census, we took six haphazardly arrayed readings on each plate of

292 dark-adapted fluorescence $\left(F_{o}\right)$, which serves as a non-destructive proxy for microalgal

293 chlorophyll $a$ density (Barranguet \& Kromkamp 2000, Honeywill et al. 2002, Serôdio et al.

294 2008). The tip of the fiber-optic measuring head of the fluorometer was fitted with a $10 \mathrm{~mm}$

295 spacer to maintain a fixed distance from the plate surface, and the opening covered an area of 53

$296 \mathrm{~mm}^{2}$. The tip was held in place at each measurement site until the $F_{o}$ value stabilized (typically

297 3-5 seconds) before recording a value, as recommended by the manufacturer. As the amount of

298 surface moisture can affect $F_{o}$ values (Maggi et al. 2013), we restricted sampling to periods when

299 the plates were moist, but not actively splashed or submerged by the tide.

$300 \quad$ We used a generalized least squares linear model from R package nlme (Pinheiro \& Bates

$3012000)$ to assess the relationship between $\log _{e}$-transformed algal fluorescence $\left(F_{o}\right)$ during each

302 census period and average daily maximum temperature, with limpet species (or grazer exclusion

303 plates) as a fixed factor. The temporal correlation of $F_{o}$ values on individual plates across the

304 census periods was incorporated using a AR(1) autoregressive correlation structure (Pinheiro \&

305 Bates 2000). A fixed effect of shore level $(1.4 \mathrm{~m}$ or $1.7 \mathrm{~m})$ was initially included in the model, but

306 was non-significant based on likelihood ratio tests, so it was removed from the final model, and

307 plates from both shore heights were pooled. For the model of limpet growth rate (shell + tissue

308 mass change relative to initial mass, $\mathrm{mg} \mathrm{day}^{-1}$ ) in each census period, we used a linear mixed

309 effects model to evaluate the interacting fixed effects of average daily maximum temperature

310 during a census period, our proxy for log-transformed algal density $\left(F_{o}\right)$ at the start of each

311 census period, and limpet species identity $(n=1152$ observations among 359 limpets across 6

312 census periods). The model included a random effect for plates and a random effect for 
313 individual limpets nested within plates to account for nesting and for repeated measures of

314 individual limpets across census periods. Log-transformed $F_{o}$ from the start of each census

315 period was also included as a random covariate to account for temporal autocorrelation, and the

316 model included an $\mathrm{AR}(1)$ correlation structure for the random factors. While there are numerous

317 ways to describe the temperature conditions in the field, we used the average daily maximum

318 temperature during a census period to summarize the differences between plates deployed in

319 different microhabitats. Model residuals were checked for normality and for evidence of

320 heterogeneity of variances. All analyses were carried out in R 3.1.1 (R Development Core Team

$3212014)$.

322

323 Estimating cumulative respiration

324 Using the temperature records from a subset of experimental plates and the data from our

325 respiration trials, we estimated the cumulative respired $\mathrm{O}_{2}$ of an average sized limpet of each

326 species on the coolest and warmest plates (2 plates per species) on which that species was

327 present in the field experiment, for the entire period from June to December 2013. We chose to

328 use the single lowest variation and single highest variation plate for each species to encompass

329 the full range of temperature variation the limpets might have experienced in the field

330 experiment. Because the experimental plates were alternately submerged and emersed by the

331 tides, we used NOAA tide records for Monterey, CA to determine when plates were likely

332 submerged at high tide, and used respiration rates from the aquatic respiration trials for those

333 time periods. All other time periods used the aerial respiration data. The respiration rate at a

334 given temperature ( $\mu$ mol $\mathrm{O}_{2} \mathrm{hr}^{-1} \mathrm{~g}^{-1}$ dry tissue mass) was multiplied by the dry tissue mass of a

335 representative average sized limpet of each species and assumed constant for a 12 minute 
336 interval to estimate the respired $\mu \mathrm{mol}$ of $\mathrm{O}_{2}$ for each time step. When the temperature for a time

337 point fell between two of the respiration trial temperatures, we used linear interpolation between

338 the two closest trial temperatures to estimate respiration at the intermediate temperature. For any

339 temperatures that fell below the limits of our respiration trial temperatures, we used the

340 respiration rate value for the lowest trial temperature.

\section{Results}

\section{Respiration}

All four species of Lottia limpets showed an increase in aerial respiration rate as

344 temperatures rose until reaching a peak temperature after which respiration dropped as limpets

345 entered heat coma (Figure 3A, closed symbols). L. scabra, the high shore species often found in

346 sun-exposed horizontal microhabitats, had the highest temperature of peak respiration at $37.5^{\circ} \mathrm{C}$.

347 The high-shore, vertical-wall-favoring species L. austrodigitalis and the low-shore sun-exposed

348 L. limatula both had a peak respiration rate near $35^{\circ} \mathrm{C}$. The low-shore species L. pelta, which

349 favors cooler wave-exposed vertical walls, had the lowest peak respiration temperature at 32.5

$350{ }^{\circ} \mathrm{C}$. By $40{ }^{\circ} \mathrm{C}$ all of the species exhibited a decline in respiration rate, likely indicative of heart

351 failure and heat coma (Bjelde \& Todgham 2013). Our range of trial temperatures and the high

352 peak temperature of respiration for L. scabra did not allow for a proper estimation of a break

353 temperature for that species, but the break temperatures of the other species were lower than the

354 likely break point for L. scabra near $37^{\circ} \mathrm{C}$ (Table 1). All four species exhibited their highest $\mathrm{Q}_{10}$

355 values between 10 and $20^{\circ} \mathrm{C}$ (4.3 for L. scabra, 2.3 for L. austrodigitalis, 2.9 for L. limatula, and

3562.2 for L. pelta, Figure 3B). Each species showed a relaxation in $\mathrm{Q}_{10}$ to the $1.1-1.5$ range

357 between $20^{\circ} \mathrm{C}$ and $30^{\circ} \mathrm{C}$, with a brief increase in $\mathrm{Q}_{10}$ prior to the peak respiration temperature. 
For the narrower range of water temperatures used in the aquatic trials, changes in

respiration rate were much smaller than the aerial trials (Figure 3A, open symbols) with overlapping $95 \%$ confidence intervals at all temperatures from 10 to $17.5^{\circ} \mathrm{C}$. Three of the species, L. scabra, L. austrodigitalis, and L. limatula, had aquatic respiration $\mathrm{Q}_{10}$ values between 2.0 and 2.2 over the 10 to $17.5^{\circ} \mathrm{C}$ range, while L. pelta had a lower $\mathrm{Q}_{10}$ of 1.4 .

\section{Heat coma temperatures}

Each of the four limpet species exhibited symptoms of heat coma at the highest aerial respiration trial temperatures (Table 1), and there were significant differences in median $\mathrm{CT}_{\max }$ between species (Analysis of deviance for Temperature $\chi^{2}=218$, $\mathrm{df}=1, P<0.001$; Species $\chi^{2}=$ 43.9, $\mathrm{df}=3, P<0.001)$. The two high shore species, L. scabra and L. austrodigitalis had significantly higher median $\mathrm{CT}_{\max }$ values than the low shore species (L. scabra $=L$. austrodigitalis $>$ L. limatula $>$ L. pelta, Tukey post-hoc tests, $P<0.05)$. All $L$. limatula and $L$. pelta had entered heat coma at $40{ }^{\circ} \mathrm{C}$, while some representatives of $L$. scabra and $L$. austrodigitalis remained adhered and responsive at the conclusion of the $2 \mathrm{~h}$ exposure even at the highest temperature in the experiment.

\section{Field growth experiment}

The ANCOVA analysis of log-transformed dark-adapted fluorescence $F_{o}$, our proxy for algal density, showed a non-significant interaction between average daily maximum temperature and limpet species identity $\left(F_{4,350}=1.89, P=0.111\right)$, but there was a significant main effect of limpet species identity $\left(F_{4,350}=80.8, P<0.001\right)$ and the average daily maximum temperature covariate $\left(F_{1,350}=104.3, P<0.001\right.$, Table S2). Coefficient estimates for the model are given in Table S3. Tukey post-hoc tests of the main effect of limpet species (including grazer exclusions) show that the intercepts for all four limpet species treatments were significantly lower than the 
381 grazer exclusion plates, while L. pelta and L. scabra were not significantly different from each

382 other, nor were L. limatula and L. austrodigitalis. Limpet grazing reduced the amount of algae

383 on plates relative to grazer exclusions, but did not change the slope of the negative relationship

384 between algal density and average daily temperature range found on all plates (Figure 4).

385 Using the regression values for limpet mass vs. projected area in the census photographs

386 (Table S4), we were able to track limpet growth non-invasively on the experimental field plates

387 through the experiment. There was a significant three-way interaction between average daily

388 maximum temperature during a census period, log-transformed algal fluorescence at the start of

389 each census period, and limpet species identity (Table $2, F_{3,671}=8.12, P<0.001$ ). Partial effects

390 plots for the 3-way ANCOVA (Fox \& Weisberg 2011) revealed that predicted limpet growth rate

391 remained flat or increased with increasing average daily maximum temperature across a range of

392 representative $F_{o}$ values, but that the slope of the relationship differed among limpet species and

$393 \quad F_{o}$ levels (Figure 5; coefficient estimates given in Table S5).

\section{Estimated respiration in the field}

395 The experimental plates deployed in the field at HMS showed a 3-fold variation in

396 average daily temperature range from the coolest to warmest plate for each species, and a 9 to

$39713^{\circ} \mathrm{C}$ difference in maximum temperatures (Figure 6A, Table 3). Using the temperature data

398 from the coolest and warmest plates for each species, we predicted a 5 to $14 \%$ increase in

399 cumulative respired $\mu$ mol $\mathrm{O}_{2}$ for average sized limpets living on the warmest plates (Figure 6B

400 and Figure 6C, Table 3) over the entire experimental period, relative to the coolest plate. None of

401 the plates exceeded the estimated $\mathrm{CT}_{\max }$ thresholds for any of the species during the 24 weeks of

402 the experiment. 


\section{Discussion}

All four species of Lottia limpets exhibit a large increase in respiration rate with increasing temperature while aerially emersed. In seawater temperatures within the normal

406 yearly range for $\mathrm{HMS}\left(10-17.5^{\circ} \mathrm{C}\right)$, respiration rates are typically in the range of 8 to $18 \mu \mathrm{mol}$

$407 \mathrm{O}_{2} \mathrm{~h}^{-1} \mathrm{~g}^{-1}$ (dry tissue mass), but when limpets are exposed to body temperatures in air within the 408 range of extremes found at low tide, their peak respiration rates range from 30 to $60 \mu \mathrm{mol}_{2} \mathrm{~h}^{-1}$ $409 \mathrm{~g}^{-1}$. At low temperatures there was substantial overlap in aerial and aquatic respiration rates, 410 though the trend for increasing respiration rate in water appears lower than in air. A lower

411 overall respiration rate in water at higher temperatures has been observed in L. digitalis (Bjelde

412 \& Todgham 2013), but other intertidal species such as Pisaster seastars show the opposite

413 pattern, with higher aquatic respiration rates than aerial respiration rates at the same temperature 414 (Fly et al. 2012).

415 We see some evidence for differential respiration responses and susceptibility to heat 416 stress while emersed between the low shore species (L. pelta and L. limatula), and the high shore 417 species (L. austrodigitalis and L. scabra). Both high shore species have higher median $\mathrm{CT}_{\max }$ 418 values and maintain slightly lower aerial respiration rates from 25 to $32.5{ }^{\circ} \mathrm{C}$ than the low shore 419 species. L. pelta, the low shore species that is typically found on vertical faces, in wave-exposed 420 microhabitats, or hiding under algal cover, is the least tolerant of prolonged aerial emersion at 421 high temperatures and had the lowest $\mathrm{CT}_{\max }$ and lowest temperature of peak respiration, though 422 interestingly it also maintains a relatively high aerial respiration rate at temperatures common in 423 those cool microhabitats. It may be the case that L. pelta is particularly adapted to maximizing 424 metabolism and growth in cool microhabitats, at the cost of reduced tolerance to higher 425 temperatures. The second low shore species, L. limatula, which inhabits similar microhabitats as 
426 L. pelta but is also often found on horizontal, sun-exposed rocks in the low and mid-shore zone,

427 shows the most drastic increase in aerial respiration rate, increasing nearly 6 -fold over the 10 to

$42835^{\circ} \mathrm{C}$ range. Both low shore species had estimated respiration break points within one degree of

429 their median $\mathrm{CT}_{\max }$ values, so that the range of temperatures where maximum respiration rate

430 occurred was followed closely by the onset of heat coma. In contrast, L. austrodigitalis, which is

431 the highest-living limpet species on the shore at HMS, limits its respiration rate increase to half

432 that of $L$. limatula across that same temperature range, perhaps reflecting a need to limit energy

433 expenditure during the frequent prolonged aerial emersion periods that come from living high on

434 the shore and the reduced availability of algal food resources to support a high metabolic rate.

435 The $\mathrm{CT}_{\max }$ for L. austrodigitalis was $4{ }^{\circ} \mathrm{C}$ higher than the estimated respiration break point

436 temperature, indicating that this high shore species can maintain attachment to the rock and

437 avoid signs of heat coma longer after its respiration has begun to falter. The other high shore

438 species, L. scabra, is typically found in warmer microhabitats than L. austrodigitalis, living on

439 horizontal, sun-exposed rocks that occasionally reach the highest intertidal temperatures at HMS.

440 While L. scabra exhibits a slightly higher respiration rate than L. austrodigitalis, the peak rate

441 occurs at a slightly higher temperature, and is accompanied by a slightly higher $\mathrm{CT}_{\max }$, indicating

442 greater thermotolerance.

443 Each of the limpet species shows some evidence of metabolic rate control as they move

444 through the 20 to $30{ }^{\circ} \mathrm{C}$ temperature range, which is the most common range of warm, but not

445 extreme, daytime low tide rock temperatures at this site (Denny et al. 2006, Miller et al. 2009).

$446 \mathrm{Q}_{10}$ values for this temperature range typically remain below 1.5 , lower than the expected value

447 of 2 to 3 for many temperature-dependent metabolic processes (Hochachka \& Somero 2002).

448 There are a growing number of examples of intertidal organisms showing some level of 
metabolic rate control or depression during warm temperature exposures, including the limpet $L$.

450 digitalis (Bjelde \& Todgham 2013) which has an overlapping range with L. austrodigitalis in

451 Monterey Bay. Limpets from South Africa (Marshall \& McQuaid 1991) and some intertidal

452 snails also exhibit metabolic rate control (McMahon \& Russell-Hunter 1977, Sokolova et al.

453 2000, Marshall et al. 2011) in the range of warm daytime low tide temperatures, although the

454 response is not universal for intertidal gastropods (McMahon \& Russell-Hunter 1977, McMahon

455 et al. 1995). Among the tropical species that exhibit metabolic rate depression, the magnitude of

456 that depression appears to be greater than that shown here by the temperate limpets, and it is

457 hypothesized that the more frequent and severe exposure to high temperatures in the tropics may

458 accentuate the need to control energy expenditures during prolonged emersion (Marshall et al.

459 2011). Even when there is evidence for metabolic rate control at moderate warm temperatures in

460 intertidal molluscs, $\mathrm{Q}_{10}$ values still tend to increase at the extreme limits of thermotolerance

461 (Marshall et al. 2011), as seen with all four limpet species measured here.

462 In the field, we observe a strong negative relationship between average daily maximum

463 temperature and algal fluorescence $\left(F_{o}\right)$ on plates in different thermal microhabitats. The effect

464 of limpet grazing lowers algal density compared to grazer exclusion plates, but does not change

465 the negative relationship with increasing temperature. The greater amount of variability in $F_{o}$

466 values on "No grazer" plates may be due to a combination of factors related to plate location on

467 the shore, including exposure to sun or shading, wave splash, and the presence of small

468 opportunistic grazers such as Littorina snails that may have crawled through the mesh fence and

469 grazed the plates at some sites. Additionally, the consistent feeding of limpets on the grazed

470 plates may serve to mute the inherent variability in microalgal density along the shore. For the

471 limpets growing on those plates, the interacting effects of algal availability and temperature 
472 across plates led to flat or slightly positive growth rates with increasing maximum temperature 473 and algal resources.

474 The observed increase in growth rates on warmer experimental plates, at least in the

475 presence of higher algal densities for L. austrodigitalis and L. scabra, supports the possibility of 476 a potential benefit to mild increases in low tide temperature above the predominant sea surface

477 temperature range. On the warmest plates measured here, limpets spent only $10 \%$ of the total 478 time at temperatures above $20^{\circ} \mathrm{C}$ during the 24 week field experiment (Figure 1B shows

479 representative data for two L. scabra plates), and never exceeded the estimated $\mathrm{CT}_{\max }$ limits for 480 any of the species. The predictions of increases in cumulative respired $\mathrm{O}_{2}$ on the warmest plates 481 ranged from 5 to $14 \%$, but the increased respiration did not manifest as significant decreases in 482 growth rate. The positive or neutral interactive effects of algal density with temperature on 483 limpet growth rates seem to outweigh the negative effects of increasing temperature alone. In 484 fully aquatic habitats, if there is sufficient food to support higher metabolic rates, growth rates 485 often increase (O'Connor 2009, Pangle \& Peacor 2010, O'Regan et al. 2014), and the 486 combination of warmer waters and warmer low tide conditions between sites on the coast has 487 also been implicated in faster growth rates in mussels and other intertidal consumers (Phillips 488 2005, Blanchette et al. 2007). In the current experiment, where ocean temperature is consistent 489 across all of our microsites, we see evidence for positive effects of warmer low tide conditions 490 alone. However, it is important to reiterate that these low tide temperature conditions were 491 primarily non-stressful, and that low tide temperatures approaching the $\mathrm{CT}_{\max }$ values of the 492 limpets species did not occur. Conditions on our temperate shoreline are only rarely stressful 493 enough to reach critical thermal maxima, in contrast to tropical sites where limpets and other 494 high shore grazers may routinely experience near-lethal temperatures (Williams \& Morritt 1995, 
495 Williams et al. 2005, Marshall et al. 2010, Dong et al. 2014), and so further warming in more 496 stressful tropical regions will likely have predominantly negative effects.

497 There are several caveats to this general conclusion of beneficial effects of increased

498 microalgal densities and warmer temperatures on limpet growth rates. All four limpet species

499 graze microalgae and diatoms from the substratum, but the different thermal environments in our

500 field experiment may drive differences in algal growth rate and species identity that could

501 change the available energy for limpet growth (Castenholz 1961). Although we observed a

502 general decline in algal density on plates with increasing temperature, we lack information on the

503 species composition of the microalgal communities on the different plates, or their nutritional

504 value. A second caveat is that our estimates of cumulative respiration are based only on rates for

505 limpets at rest during a single acute exposure in air or seawater. Particularly following a high-

506 temperature aerial exposure, the post-exposure period during the next high tide may bring

507 prolonged increased respiration rates to accommodate an increased metabolic demand needed for

508 the heat-shock response that drives repair or degradation of damaged proteins (Dong et al. 2008,

509 Bjelde \& Todgham 2013). There could also be a need to recover from anaerobic metabolism

510 (Ellington 1983), though there is no evidence of anaerobic metabolic end product accumulation

511 in L. digitalis from central California following aerial exposure (Bjelde \& Todgham 2013). Due

512 to these potential additional metabolic demands, our long-term estimates of cumulative

513 respiration may underestimate the respired $\mathrm{O}_{2}$, particularly on days when temperatures do reach

514 stressful levels during low tide, although this makes the pattern of increased growth rate in

515 warmer microsites all the more surprising. Finally, it should be noted that the limpets utilized in

516 these experiments represent sub-adult and small adult size classes, but we have no performance

517 information for smaller limpets. Smaller limpets should have higher mass-specific metabolic 
518 rates and reduced energy stores relative to larger limpets, factors that may enhance the impacts of

519 emersed temperature stress on newly recruited individuals (Davies 1966, Kiørboe \& Hirst 2014).

520 The thermal response curves measured here should be contrasted with the types of curves

521 typically reported for organisms such as lizards or insects (Angilletta 2009). The peak in

522 respiration we observe for limpet temperatures approaching $40{ }^{\circ} \mathrm{C}$ may have a different

523 interpretation than a thermal performance curve representing other metrics such as feeding rate,

524 locomotion speed, growth rate, or fecundity. For those other metrics, temperatures at the peak of

525 the performance curve might well be the most desirable place to spend time from the standpoint

526 of individual or population growth. In contrast, our measure of respiration rate, as a metric of

527 metabolic rate and calorie consumption, is somewhat removed from true measures of organismal

528 fitness. While we observe a peak in respiration at temperatures in the 32.5 to $37.5^{\circ} \mathrm{C}$ range, it is

529 not clear those temperatures necessarily represent a true "performance peak" or "optimum",

530 particularly as temperatures in this range are known to induce a heat shock response in limpets

531 (Dong et al. 2008, Bjelde \& Todgham 2013). Instead, for whole-organism fitness, limpet body

532 temperatures slightly below the range of peak respiration rates may be closer to an optimum

533 (Martin \& Huey 2008), particularly if they avoid the risk and associated cost of a heat shock

534 response but allow for faster catabolic and anabolic rates.

535 Lottia limpets at HMS show a clear rise in respiration rate in response to rising body

536 temperature during aerial emersion, and a quick decline in respiration as they reach extreme high

537 temperatures that induce heat coma. The two high shore species, L. scabra and L. austrodigitalis,

538 maintain slightly lower respiration rates during intermediate temperatures in the 20 to $30{ }^{\circ} \mathrm{C}$

539 range than their low shore counterparts, and have a higher $\mathrm{CT}_{\max }$, in line with the expectation

540 that the frequency and severity of high temperature exposures should be higher in the upper 
541 littoral zone. In tracking growth over several months in the field, we see little evidence for

542 decreased growth in microhabitats with higher temperature variability and attendant higher peak

543 temperatures, despite estimated respiration demands being at least 5 to $14 \%$ higher, and in some

544 cases we observe increased growth rates in warmer sites when food is abundant. The relatively

545 short amount of total time encompassed by warm low tide exposures may have a small impact on

546 growth rates, but when the majority of those exposures avoid stressful extreme temperatures,

547 warmer microhabitats may be beneficial for intertidal consumers. Faster metabolic rates among

548 limpets could drive increased grazing effort at high tide to support greater metabolic demand and

549 increase growth rates, strengthening top-down control of microalgal density on the shore.

550 However, given the negative relationship between warmer low tide temperatures and microalgal

551 density observed in our grazer exclusion treatments, there is an opportunity for negative

552 feedback on limpet growth if algal growth rates cannot support increased grazing pressure from

553 limpets. Ultimately, the impacts of climate warming on energy transfer and growth rates in

554 intertidal habitats will be determined by this interaction between rising temperatures and species'

555 individual temperature responses that are likely optimized for intermediate temperature ranges.

556 The present day variation in temperature over small spatial scales in the intertidal (Denny et al.

557 2011) encompasses conditions that could increase growth rates in some instances, but continuing

558 warming of low tide aerial temperatures could begin to push organisms past their performance

559 optima. 
562 This work was supported by NSF grant OCE-1131038 and 1130095 to B. J. Allen and M. W.

563 Denny. We thank E. Duncan, J. McNamara, B. Pagan, T. Kroupa, and C. Prince for assistance in

564 the setting up the experiments and assisting with field work.

\section{Data Accessibility}

567 Data related to this paper are deposited in the Stanford University Libraries Digital Repository at $568 \mathrm{http} / /$ purl.stanford.edu/mz343tz6255. The project is registered with the NSF Biological and 569 Chemical Oceanography Data Management Office (BCO-DMO; http///www.bco-dmo.org/) 570 under grant numbers OCE-1131038 and OCE-1130095.

\section{$571 \quad$ Literature cited}

572 Allen BJ, Levinton JS (2014) Sexual selection and the physiological consequences of habitat $573 \quad$ choice by a fiddler crab. Oecologia 176:25-34

574 Angilletta MJ (2009) Thermal Adaptation: A Theoretical and Empirical Synthesis, Vol. Oxford $575 \quad$ University Press

576 Angilletta MJ, Huey RB, Frazier MR (2010) Thermodynamic effects on organismal 577 performance: is hotter better? Physiol Biochem Zool 83:197-206

578 Barranguet C, Kromkamp J (2000) Estimating primary production rates from photosynthetic 579 electron transport in estuarine microphytobenthos. Mar Ecol Prog Ser 204:39-52

580 Bayne BL, Scullard C (1978) Rates of feeding by Thais (Nucella) lapillus (L.). J Exp Mar Biol $581 \quad$ Ecol 32:113-129 
582 Benson BB, Krause Jr D (1984) The concentration and isotopic fractionation of oxygen

583 dissolved in freshwater and seawater in equilibrium with the atmosphere. Limnol

$584 \quad$ Oceanogr 29:620-632

585 Bjelde B, Todgham A (2013) Thermal physiology of the fingered limpet Lottia digitalis under emersion and immersion. J Exp Biol 216:2858-2869

587 Blanchette CA, Helmuth BST, Gaines SD (2007) Spatial patterns of growth in the mussel,

588 Mytilus californianus, across a major oceanographic and biogeograpic boundary at Point

589 Conception, California, USA. J Exp Mar Biol Ecol 340:126-148

590 Branch GM (1981) The biology of limpets: physical factors, energy flow, and ecological

591 interactions. Oceanogr Mar Biol, Annu Rev 19:235-380

592 Brett JR, Higgs DA (1970) Effect of temperature on the rate of gastric digestion in fingerling sockeye salmon, Oncorhynchus nerka. J Fish Res Board Can 27:1767-1779

594 Castenholz RW (1961) Effect of grazing on marine littoral diatom populations. Ecology 42:783$595 \quad 794$

596 Collins LS (1976) Abundance, substrate angle, and desiccation resistance in two sympatric $597 \quad$ species of limpets. Veliger 19:199-203

598 Craig PC (1968) The activity pattern and food habits of the limpet Acmaea pelta. Veliger 11:13$599 \quad 19$

600 Crummett L, Eernisse D (2007) Genetic evidence for the cryptic species pair, Lottia digitalis and 601 Lottia austrodigitalis and microhabitat partitioning in sympatry. Mar Biol 152:1-13

602 Davies PS (1966) Physiological ecology of Patella. I. The effect of body size and temperature on 603 metabolic rate. J Mar Biol Assoc U K 46:647-658 
604 Davison AC, Hinkley DV (1997) Bootstrap methods and their application, Vol. Cambridge

$605 \quad$ University Press, Cambridge

606 Denny MW, Dowd WW, Bilir L, Mach KJ (2011) Spreading the risk: Small-scale body

607 temperature variation among intertidal organisms and its implications for species

608 persistence. J Exp Mar Biol Ecol 400:175-190

609 Denny MW, Harley CDG (2006) Hot limpets: predicting body temperature in a conductance-

610 mediated thermal system. J Exp Biol 209:2409-2419

611 Denny MW, Hunt LJH, Miller LP, Harley CDG (2009) On the prediction of extreme ecological

612 events. Ecol Monogr 79:397-421

613 Denny MW, Miller LP, Harley CDG (2006) Thermal stress on intertidal limpets: long-term

614 hindcasts and lethal limits. J Exp Biol 209:2420-2431

615 Deutsch CA, Tewksbury JJ, Huey RB, Sheldon KS, Ghalambor CK, Haak DC, Martin PR (2008)

616 Impacts of climate warming on terrestrial ectotherms across latitude. Proc Natl Acad Sci

$617 \quad$ USA $105: 6668-6672$

618 Diefenbach COdC (1975) Gastric function in Caiman crocodilus (Crocodylia: Reptilia)-I. Rate

619 of gastric digestion and gastric motility as a function of temperature. Comp Biochem

$620 \quad$ Physiol A 51:259-265

621 Dong Y-w, Han G-d, Huang X-w (2014) Stress modulation of cellular metabolic sensors: interaction of stress from temperature and rainfall on the intertidal limpet Cellana toreuma. Mol Ecol 23:4541-4554

624 Dong Y, Miller LP, Sanders JG, Somero GN (2008) Heat-shock protein 70 (Hsp70) expression

625 in four limpets of the genus Lottia: interspecific variation in constitutive and inducible

626 synthesis correlates with in situ exposure to heat stress. Biol Bull 215:173-181 
627 Dong Y, Somero GN (2009) Temperature adaptation of cytosolic malate dehydrogenase of 628 limpets (genus Lottia): differences in stability and function due to minor changes in sequence correlate with biogeographic and vertical distributions. J Exp Biol 212:169-177

630 Eaton CM (1968) The activity and food of the file limpet Acmaea limatula. Veliger 11:5-12

631 Ellington WR (1983) The recovery from anaerobic metabolism in invertebrates. J Exp Zool $228: 431-444$

633 Elliott $\mathrm{J}$ (1976) The energetics of feeding, metabolism and growth of brown trout (Salmo trutta L.) in relation to body weight, water temperature and ration size. The Journal of Animal

Elliott JM (1982) The effects of temperature and ration size on the growth and energetics of Ecology 45:923-948 salmonids in captivity. Comp Biochem Physiol B 73:81-91

Feder ME, Hofmann GE (1999) Heat-shock proteins, molecular chaperones, and the stress response: evolutionary and ecological physiology. Annu Rev Physiol 61:243-282

640 Fly EK, Monaco CJ, Pincebourde S, Tullis A (2012) The influence of intertidal location and temperature on the metabolic cost of emersion in Pisaster ochraceus. J Exp Mar Biol Ecol 422-423:20-28

Fox J, Weisberg S (2011) An R Companion to Applied Regression, Vol. SAGE Publications, Thousand Oaks, CA

Gilman SE (2006) Life at the edge: an experimental study of a poleward range boundary. Oecologia 148:270-279

Hahn T, Denny M (1989) Tenacity-mediated selective predation by oystercatchers on intertidal limpets and its role in maintaining habitat partitioning by Collisella scabra and Lottia digitalis. Mar Ecol Prog Ser 53:1-10 
650 Hawkins SJ, Hartnoll RG (1983) Grazing of intertidal algae by marine invertebrates. Oceanogr $651 \quad$ Mar Biol, Annu Rev 21:195-282

652 Helmuth B (1999) Thermal biology of rocky intertidal mussels: quantifying body temperatures 653 using climatological data. Ecology 80:15-34

654 Hertz PE, Huey RB, Stevenson R (1993) Evaluating temperature regulation by field-active 655 ectotherms: the fallacy of the inappropriate question. Am Nat 142:796-818

656 Hochachka PW, Somero GN (2002) Biochemical Adaptation: Mechanism and Process in 657 Physiological Evolution, Vol. Oxford University Press, New York, USA

658 Hoekman D (2010) Turning up the heat: Temperature influences the relative importance of top659 down and bottom-up effects. Ecology 91:2819-2825

660 Honeywill C, Paterson D, Hagerthey S (2002) Determination of microphytobenthic biomass 661 using pulse-amplitude modulated minimum fluorescence. European Journal of Phycology

663 Huey RB (1991) Physiological consequences of habitat selection. Am Nat 137:S91-S115

664 Huey RB, Stevenson RD (1979) Integrating thermal physiology and ecology of ectotherms: A 665 discussion of approaches. Am Zool 19:357-366

666 Hunt LJH, Denny MW (2008) Desiccation protection and disruption: a trade-off for an intertidal 667 marine alga. J Phycol 44:1164-1170

668 Iles AC (2014) Towards predicting community level effects of climate: Relative temperature 669 scaling of metabolic and ingestion rates. Ecology 95:2657-2668

670 Jones NS (1948) Observations and experiments on the biology of Patella vulgata at Port St.

671 Mary, Isle of Man. Proc Trans Liverpool Biol Soc 56:60-77 
672 Jones SJ, Mieszkowska N, Wethey DS (2009) Linking thermal tolerances and biogeography:

673 Mytilus edulis (L.) at its southern limit on the east coast of the United States. Biol Bull

$674 \quad 217: 73$

675 Kiørboe T, Hirst AG (2014) Shifts in Mass Scaling of Respiration, Feeding, and Growth Rates across Life-Form Transitions in Marine Pelagic Organisms. Am Nat 183:E118-E130

677 Kratina P, Greig HS, Thompson PL, Carvalho-Pereira TSA, Shurin JB (2012) Warming modifies trophic cascades and eutrophication in experimental freshwater communities. Ecology 93:1421-1430

680 Kroeker KJ, Gaylord B, Hill TM, Hosfelt JD, Miller SH, Sanford E (2014) The role of temperature in determining species' vulnerability to ocean acidification: A case study using Mytilus galloprovincialis. PLoS ONE 9:e100353

Largen MJ (1967) The influence of water temperature upon the life of the dog-whelk Thais lapillus (Gastropoda: Prosobranchia). J Anim Ecol 36:207-214

Maggi E, Jackson AC, Tolhurst T, Underwood AJ, Chapman MG (2013) Changes in microphytobenthos fluorescence over a tidal cycle: implications for sampling designs. Hydrobiologia 701:301-312

Marshall DJ, Dong Y-w, McQuaid CD, Williams GA (2011) Thermal adaptation in the intertidal snail Echinolittorina malaccana contradicts current theory by revealing the crucial roles of resting metabolism. J Exp Biol 214:3649-3657

691 Marshall DJ, McQuaid CD (1991) Metabolic rate depression in a marine pulmonate snail: preadaptation for a terrestrial existence? Oecologia 88:274-276

693 Marshall DJ, McQuaid CD, Williams GA (2010) Non-climatic thermal adaptation: implications 
695 Martin Tara L, Huey Raymond B (2008) Why "suboptimal” is optimal: Jensen's Inequality and $696 \quad$ ectotherm thermal preferences. Am Nat 171:E102-E118

697 McMahon RF, Russell-Hunter WD (1977) Temperature relations of aerial and aquatic respiration 698 in six littoral snails in relation to their vertical zonation. Biol Bull 152:182-198

699 McMahon RF, Russell-Hunter WD, Aldridge DW (1995) Lack of metabolic temperature

700 compensation in the intertidal gastropods, Littorina saxatilis (Olivi) and L. obtusata (L.).

$701 \quad$ Hydrobiologia 309:89-100

702 Miller AC (1968) Orientation and movement of the limpet Acmaea digitalis on vertical rock $703 \quad$ surfaces. Veliger 11:30-44

704 Miller LP (2013) The effect of water temperature on drilling and ingestion rates of the dogwhelk $705 \quad$ Nucella lapillus feeding on Mytilus edulis mussels in the laboratory. Mar Biol 160:1489$706 \quad 1496$

707 Miller LP, Harley CDG, Denny MW (2009) The role of temperature and desiccation stress in 708 limiting the local-scale distribution of the owl limpet, Lottia gigantea. Funct Ecol 23:756$709 \quad 767$

710 Miller LP, Matassa CM, Trussell GC (2014) Climate change enhances the negative effects of 711 predation risk on an intermediate consumer. Glob Change Biol 20:3834-3844

712 Morelissen B, Harley CDG (2007) The effects of temperature on producers, consumers, and 713 plant-herbivore interactions in an intertidal community. J Exp Mar Biol Ecol 348:162$714 \quad 173$

715 Muggeo VMR (2008) segmented: an R package to fit regression models with broken-line 716 relationships. In: R News, Book 8 
717 Muñoz JLP, Finke GR, Camus PA, Bozinovic F (2005) Thermoregulatory behavior, heat gain,

718 and thermal tolerance in the periwinkle Echinolittorina peruviana in central Chile. Comp

$719 \quad$ Biochem Physiol A 142:92-98

720 Murphy PC (1978) Collisella austrodigitalis sp. nov.: A sibling species of limpet (Acmaeidae)

721 discovered by electrophoresis. Biol Bull 155:193-206

722 O'Connor MI (2009) Warming strengthens an herbivore-plant interaction. Ecology 90:388-398

723 O’Connor MI, Piehler MF, Leech DM, Anton A, Bruno JF (2009) Warming and resource

724 availability shift food web structure and metabolism. PLoS Biol 7:e1000178

725 O'Regan SM, Palen WJ, Anderson SC (2014) Climate warming mediates negative impacts of

726 rapid pond drying for three amphibian species. Ecology 95:845-855

727 Pangle KL, Peacor SD (2010) Temperature gradients, not food resource gradients, affect growth

728 rate of migrating Daphnia mendotae in Lake Michigan. J Gt Lakes Res 36:345-350

729 Phillips NE (2005) Growth of filter-feeding benthic invertebrates from a region with variable

730 upwelling intensity. Mar Ecol Prog Ser 295:79-89

731 Pincebourde S, Sanford E, Casas J, Helmuth B (2012) Temporal coincidence of environmental

732 stress events modulates predation rates. Ecol Lett 15:680-688

733 Pincebourde S, Sanford E, Helmuth B (2008) Body temperature during low tide alters the

734 feeding performance of a top intertidal predator. Limnol Oceanogr 53:1562-1573

735 Pinheiro JC, Bates DM (2000) Mixed-effects models in S and S-PLUS, Vol. Springer Verlag, $736 \quad$ New York

737 Pörtner HO (2012) Integrating climate-related stressor effects on marine organisms: unifying 738 principles linking molecule to ecosystem-level changes. Mar Ecol Prog Ser 470:273-290 
739 R Development Core Team (2014) R: A language and environment for statistical computing. In. 740 R Foundation for Statistical Computing, Vienna, Austria

741 Rasband WS (1997-2014) ImageJ. In. U. S. National Institutes of Health, Bethesda, Maryland, $742 \quad$ USA

743 Sanford E (1999) Regulation of keystone predation by small changes in ocean temperature. Science 283:2095-2097

745 Sanford E (2002) Water temperature, predation, and the neglected role of physiological rate effects in rocky intertidal communities. Integr Comp Biol 42:881-891

747 Sanford E, Menge BA (2001) Spatial and temporal variation in barnacle growth in a coastal $748 \quad$ upwelling system. Mar Ecol Prog Ser 209:143-157

749 Serôdio J, Vieira S, Cruz S (2008) Photosynthetic activity, photoprotection and photoinhibition 750 in intertidal microphytobenthos as studied in situ using variable chlorophyll fluorescence. $751 \quad$ Cont Shelf Res 28:1363-1375

752 Sokolova IM, Granovitch AI, Berger VJ, Johannesson K (2000) Intraspecific physiological variability of the gastropod Littorina saxatilis related to the vertical shore gradient in the White and North Seas. Mar Biol 137:297-308

755 Stich HB, Lampert W (1984) Growth and reproduction of migrating and non-migrating Daphnia species under simulated food and temperature conditions of diurnal vertical migration. Oecologia 61:192-196

758 Stillman JH (2002) Causes and consequences of thermal tolerance limits in rocky intertidal 759 porcelain crabs, genus Petrolisthes. Integr Comp Biol 42:790-796

760 Stillman JH (2003) Acclimation capacity underlies susceptibility to climate change. Science 761 301:65 
762 Sutherland JP (1970) Dynamics of high and low populations of the limpet, Acmaea scabra 763 (Gould). Ecol Monogr 40:169-188

764 Tewksbury JJ, Huey RB, Deutsch CA (2008) Putting the heat on tropical animals. Science 320:1296-1297

766 Tomanek L (2002) The heat-shock response: its variation, regulation, and ecological importance

767 in intertidal gastropods (genus Tegula). Integr Comp Biol 42:797-807

768 Tomanek L, Somero GN (1999) Evolutionary and acclimation-induced variation in the heatshock responses of congeneric marine snails (Genus Tegula) from different thermal habitats: implications for limits of thermotolerance and biogeography. J Exp Biol

772 Tomanek L, Zuzow MJ (2010) The proteomic response of the mussel congeners Mytilus

773 galloprovincialis and M-trossulus to acute heat stress: implications for thermal tolerance

774 limits and metabolic costs of thermal stress. J Exp Biol 213:3559-3574

775 Walker CG (1968) Studies on the jaw, digestive system, and coelomic derivatives in

776 representatives of the genus Acmaea. Veliger 11:88-97

777 Williams GA, De Pirro M, Leun KM, Morritt D (2005) Physiological responses of heat stress on 778 a tropical shore: the benefits of mushrooming behaviour in the limpet Cellana grata. Mar 779 Ecol Prog Ser 292:213-224

780 Williams GA, Morritt D (1995) Habitat partitioning and thermal tolerance in a tropical limpet, Cellana grata. Mar Ecol Prog Ser 124:89-103

782 Wolcott TG (1973) Physiological ecology and intertidal zonation in limpets (Acmaea): a critical 783 look at limiting factors. Biol Bull 145:389-422 
784 Woodin SA, Hilbish TJ, Helmuth B, Jones SJ, Wethey DS (2013) Climate change, species

785 distribution models, and physiological performance metrics: predicting when biogeographic models are likely to fail. Ecol Evol 3:3334-3346

787 Yamane L, Gilman SE (2009) Opposite responses by an intertidal predator to increasing aquatic 788 and aerial temperatures. Mar Ecol Prog Ser 393:27-36 


\section{Tables}

793

794 Table 1. Estimated respiration break points and median heat coma temperatures $\left(\mathrm{CT}_{\max }\right)$ for

795 limpets held in air, with temperatures raised from $15^{\circ} \mathrm{C}$ to a target temperature at $10{ }^{\circ} \mathrm{C} \mathrm{h}^{-1}$ and

796 held for $2 \mathrm{~h}$. Because the peak respiration for L. scabra occurred at $37.5^{\circ} \mathrm{C}$, it was not possible

797 to estimate a break point via piecewise regression from the single temperature above the peak.

\begin{tabular}{lcc}
\hline Species & $\begin{array}{c}\text { Respiration break point } \\
\text { temperature }\left({ }^{\circ} \mathrm{C}, \pm 1 \mathrm{SE}\right)\end{array}$ & $\begin{array}{c}\text { Critical Thermal } \\
\text { Maximum }\left({ }^{\circ} \mathrm{C}, \pm 1 \mathrm{SE}\right)\end{array}$ \\
\hline L. scabra & $\mathrm{NA}$ & $39.6( \pm 0.9)$ \\
L. austrodigitalis & $34.2( \pm 1.0)$ & $38.8( \pm 0.5)$ \\
L. limatula & $36.5( \pm 0.4)$ & $36.9( \pm 0.5)$ \\
L. pelta & $34.4( \pm 0.4)$ & $34.6( \pm 0.4)$
\end{tabular}

798

799 
801 Table 2. Linear mixed effects model summary for limpet growth rate $\left(\mathrm{mg} \mathrm{day}^{-1}\right)$. Average daily

802 maximum temperature during a census period, algal density (log-transformed dark-adapted

803 fluorescence, $F_{o}$ ) at the start of a census period, and limpet species were treated as fixed factors.

804 Random effects included log-transformed algal density, experimental plates, and individual

805 limpets nested within experimental plates in order to account for nesting and repeated measures

806 through time. The model accounts for first order autocorrelation among repeated measures using

807 an $\mathrm{AR}(1)$ autoregressive structure.

\begin{tabular}{lcccc}
\hline Treatment & numDF & denDF & $F$ & $P$ \\
\hline Average Daily Maximum $\left({ }^{\circ} \mathrm{C}\right)$ & 1 & 671 & 20.36 & $<0.001$ \\
Algae density, Log $\left(F_{o}\right)$ & 1 & 671 & 17.20 & $<0.001$ \\
Species & 3 & 44 & 1.63 & 0.196 \\
Avg. Daily Max. $\times$ Algae density & 1 & 671 & 37.50 & $<0.001$ \\
Avg. Daily Max. $\times$ Species & 3 & 671 & 4.84 & 0.002 \\
Algae density $\times$ Species & 3 & 671 & 3.16 & 0.024 \\
Avg. Daily Max. $\times$ Algae density $\times$ Species & 3 & 671 & 8.12 & $<0.001$
\end{tabular}


811 Table 3. Temperature statistics for the single coolest and single warmest plate containing each

812 limpet species in the field, and estimated cumulative respiration on the coolest and warmest plate

813 over the course of the experiment from June to December 2013.

\begin{tabular}{|c|c|c|c|c|c|c|c|}
\hline \multirow[b]{2}{*}{ Species } & \multicolumn{3}{|c|}{ Cool Plate } & \multicolumn{3}{|c|}{ Warm Plate } & \\
\hline & $\begin{array}{c}\text { Average } \\
\text { daily } \\
\text { temperature } \\
\text { range, }{ }^{\circ} \mathrm{C}\end{array}$ & $\begin{array}{c}\text { Maximum } \\
\text { temperature, } \\
{ }^{\circ} \mathrm{C}\end{array}$ & $\begin{array}{c}\text { Estimated } \\
\text { cumulative } \\
\text { respired } \\
\text { oxygen, } \\
\mu \text { mol }\end{array}$ & $\begin{array}{l}\text { Average } \\
\text { daily } \\
\text { temperature } \\
\text { range, }{ }^{\circ} \mathrm{C}\end{array}$ & $\begin{array}{c}\text { Maximum } \\
\text { temperature, } \\
{ }^{\circ} \mathrm{C}\end{array}$ & $\begin{array}{c}\text { Estimated } \\
\text { cumulative } \\
\text { respired } \\
\text { oxygen, } \\
\mu m o l\end{array}$ & $\begin{array}{c}\text { Estimated } \\
\text { respiration } \\
\text { increase }\end{array}$ \\
\hline L. scabra & 3.3 & 26.0 & 1150 & 10.6 & 35.0 & 1314 & $14.3 \%$ \\
\hline L. austrodigitalis & 2.9 & 23.0 & 1383 & 8.5 & 36.5 & 1456 & $5.3 \%$ \\
\hline L. limatula & 2.4 & 21.5 & 2520 & 7.8 & 34.5 & 2732 & $8.4 \%$ \\
\hline L. pelta & 2.9 & 24.5 & 2148 & 8.2 & 33.5 & 2363 & $10.0 \%$ \\
\hline
\end{tabular}

814 


\section{$816 \quad$ Figure legends}

817 Figure 1. A) A hypothetical temperature-performance curve, where some metric of performance

818 (grazing rate, growth rate, etc.) climbs with increasing temperature towards a peak or plateau,

819 and then drops off quickly as temperatures increase further. B) Kernel density estimates of

820 limpet body temperatures from June through December 2013 at cool and warm microsites on the

821 high shore at HMS (1.7 m above Mean Lower Low Water). The gray hatched region indicates

822 the approximate portion of time spent at temperatures between 16.6 and $28{ }^{\circ} \mathrm{C}$, which are above

823 the warmest ocean temperature at the site, but below the range that typically induces a heat shock

824 response in Lottia limpets (Dong et al. 2008). The solid gray region above $28{ }^{\circ} \mathrm{C}$ represents the

825 temperature range where most Lottia exhibit a heat shock response. The samples include 3,939

826 hours of data at two sites collected at 12 minute intervals, with the kernel bandwidth set at 0.6.

827 Figure 2. A) Lottia limpets from central California. B) L. scabra and L. austrodigitalis are found

828 in the high intertidal zone, while L. limatula and L. pelta are found in the low to middle intertidal

829 zone.

830 Figure 3. Respiration rates in air and seawater, and aerial respiration $\mathrm{Q}_{10}$ values for Lottia

831 limpets. (A) Lottia limpet mass-specific aerial respiration rates (closed symbols) and aquatic

832 respiration rates (open symbols) with $95 \%$ confidence intervals. The horizontal positions of the

833 points have been staggered, but trials occurred at the temperatures indicated on the horizontal

834 axis $\left(\mathrm{n}=12\right.$ limpets per temperature). (B) Aerial respiration $\mathrm{Q}_{10}$ values for each temperature

835 range, with bootstrapped $95 \%$ confidence intervals back-transformed from log-transformed

836 samples. The upper confidence limit for L. scabra in the $10-15^{\circ} \mathrm{C}$ range $(=10.3)$ is cut off to

837 improve the clarity of the plotted values. 
838 Figure 4. Algae dark adapted fluorescence, $F_{o}$ (a proxy for algal density), on experimental plates

839 versus limpet species treatment and average daily maximum temperature in the time period

840 preceding each of six census dates between June and December 2013. Fitted lines are back-

841 transformed estimates from models fitted with log-transformed $F_{o}$ values.

842 Figure 5. Partial regression slopes ( $\pm 95 \%$ confidence limits shown in grey) from the linear

843 model of limpet growth rate versus average daily maximum temperature during a census period,

844 algal density $\left(\log F_{o}\right)$ at the start of a census period, and limpet species. Individual panels

845 illustrate the fitted relationship between average daily maximum temperature $\left({ }^{\circ} \mathrm{C}\right)$ and limpet

846 growth rate (mg day-1), for each limpet species (rows) at 3 representative algal density values

847 (left column, $F_{o}=25$; center, $F_{o}=50$; right column, $F_{o}=75$ ). The rug of points on the horizontal

848 axis represents the distribution of average daily maximum temperature values in the dataset.

849 Figure 6. Estimated respiration rates for an average size L. scabra (18.5 $\mathrm{mg}$ dry tissue mass)

850 living on the single warmest (red) and single coolest (blue) plate in the field experiment. A)

851 Temperature records for the warmest and coolest plates in the field that held L. scabra. B).

852 Estimated respiration rates for L. scabra on the warmest and coolest plates. A close up view of

853 the three day time period represented by the grey box in (B) is shown in (C), along with the

854 corresponding tides. 


\section{Figures}

(A)

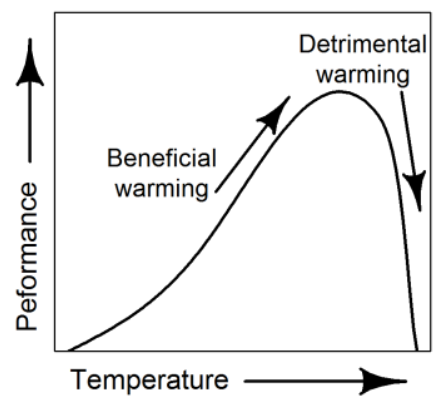

(B)

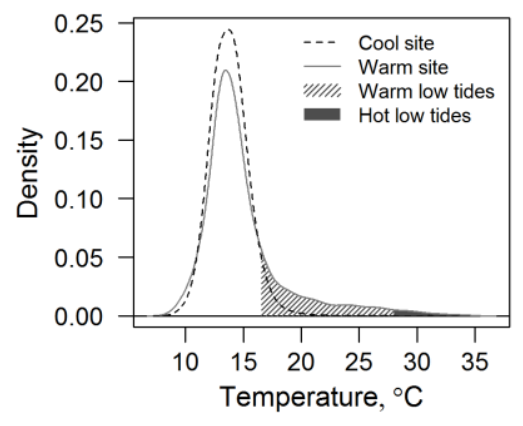

857

858 Figure 1. A) A hypothetical temperature-performance curve, where some metric of performance

859 (grazing rate, growth rate, etc.) climbs with increasing temperature towards a peak or plateau,

860 and then drops off quickly as temperatures increase further. B) Kernel density estimates of

861 limpet body temperatures from June through December 2013 at cool and warm microsites on the

862 high shore at HMS (1.7 $\mathrm{m}$ above Mean Lower Low Water). The gray hatched region indicates

863 the approximate portion of time spent at temperatures between 16.6 and $28{ }^{\circ} \mathrm{C}$, which are above

864 the warmest ocean temperature at the site, but below the range that typically induces a heat shock

865 response in Lottia limpets (Dong et al. 2008). The solid gray region above $28{ }^{\circ} \mathrm{C}$ represents the

866 temperature range where most Lottia exhibit a heat shock response. The samples include 3,939

867 hours of data at two sites collected at 12 minute intervals, with the kernel bandwidth set at 0.6. 

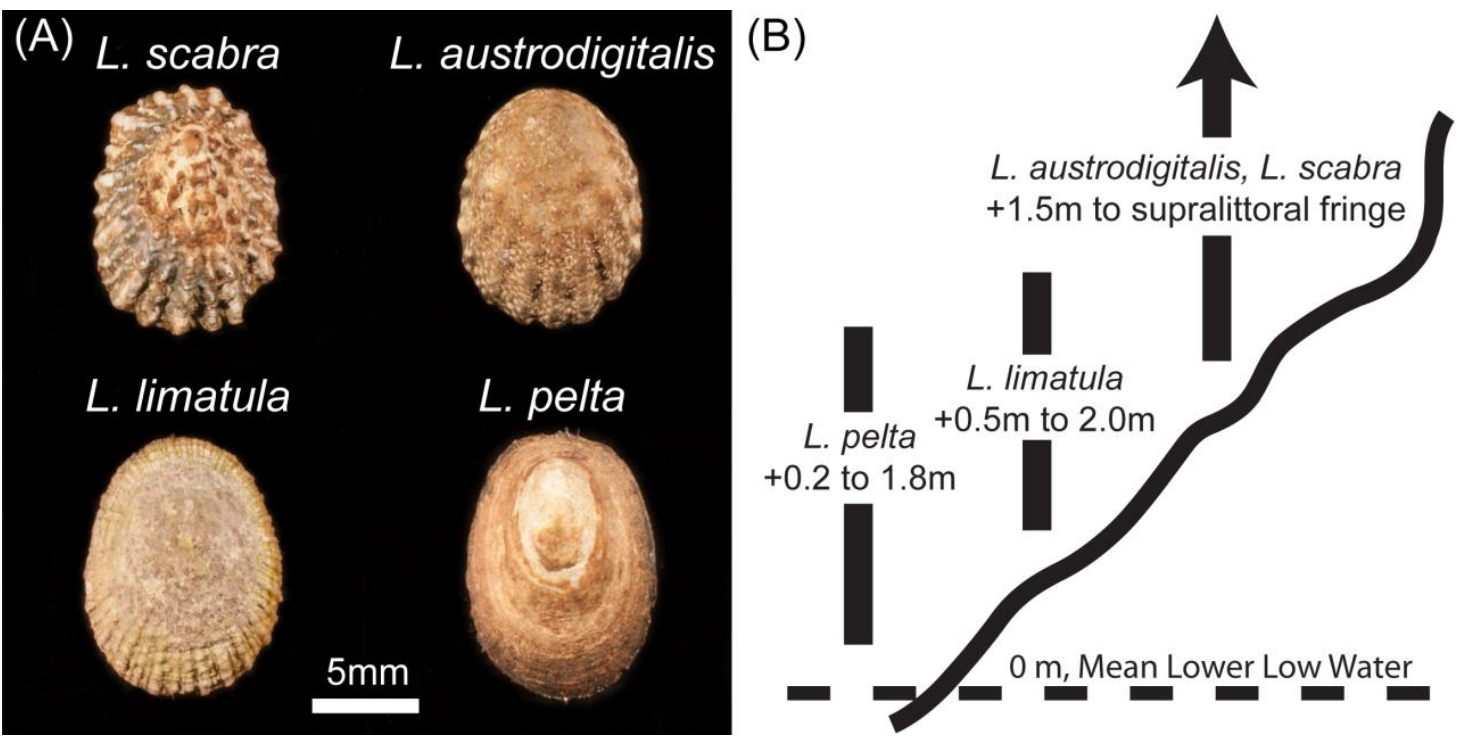

869 Figure 2. A) Lottia limpets from central California. B) L. scabra and L. austrodigitalis are found

870 in the high intertidal zone, while L. limatula and L. pelta are found in the low to middle intertidal 871 zone. 

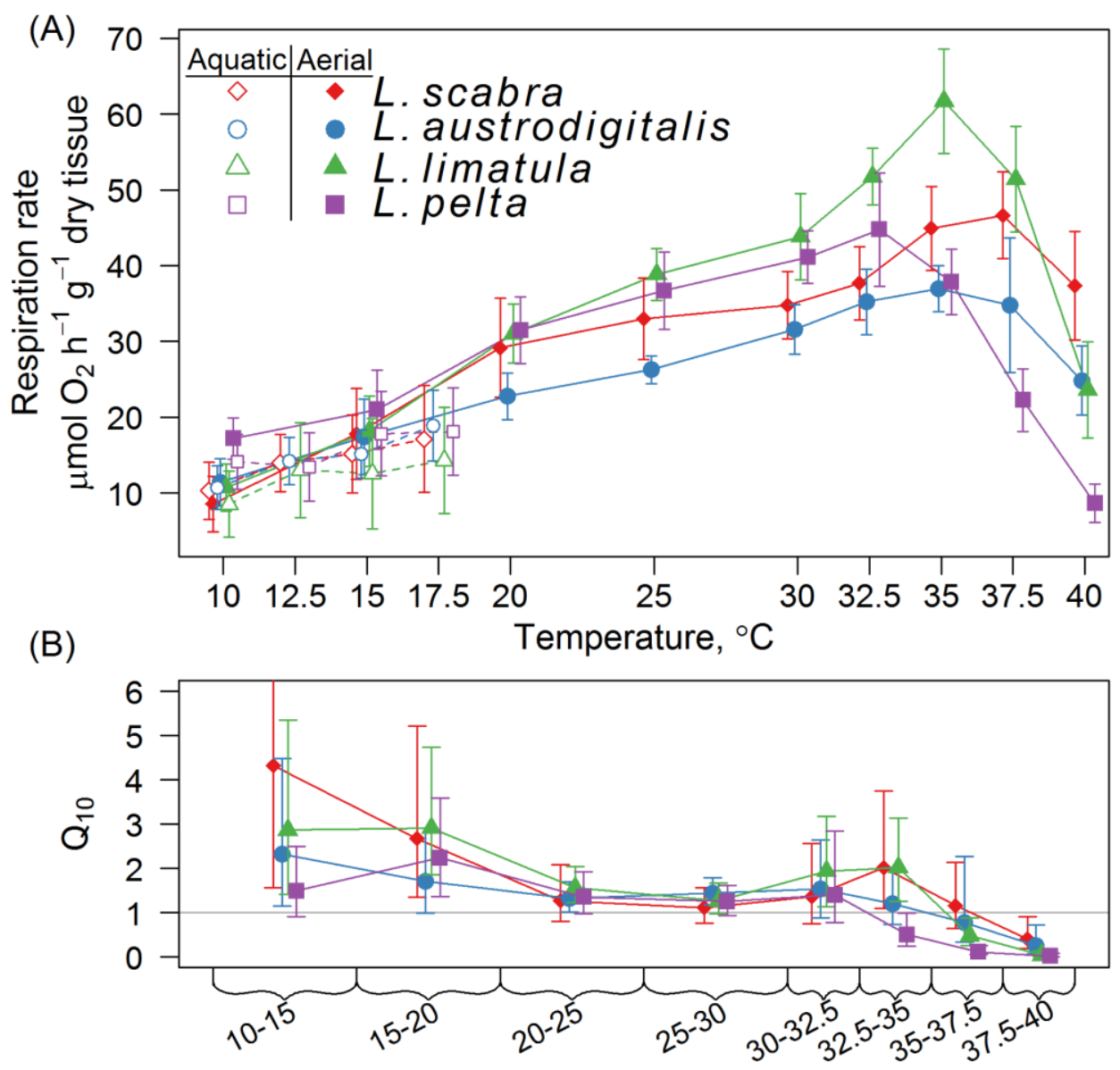

Temperature range, ${ }^{\circ} \mathrm{C}$

874 Figure 3. Respiration rates in air and seawater, and aerial respiration $\mathrm{Q}_{10}$ values for Lottia

875 limpets. (A) Lottia limpet mass-specific aerial respiration rates (closed symbols) and aquatic

876 respiration rates (open symbols) with $95 \%$ confidence intervals. The horizontal positions of the

877 points have been staggered, but trials occurred at the temperatures indicated on the horizontal

878 axis $\left(\mathrm{n}=12\right.$ limpets per temperature). (B) Aerial respiration $\mathrm{Q}_{10}$ values for each temperature

879 range, with bootstrapped $95 \%$ confidence intervals back-transformed from log-transformed

880 samples. The upper confidence limit for L. scabra in the $10-15^{\circ} \mathrm{C}$ range $(=10.3)$ is cut off to

881 improve the clarity of the plotted values. 


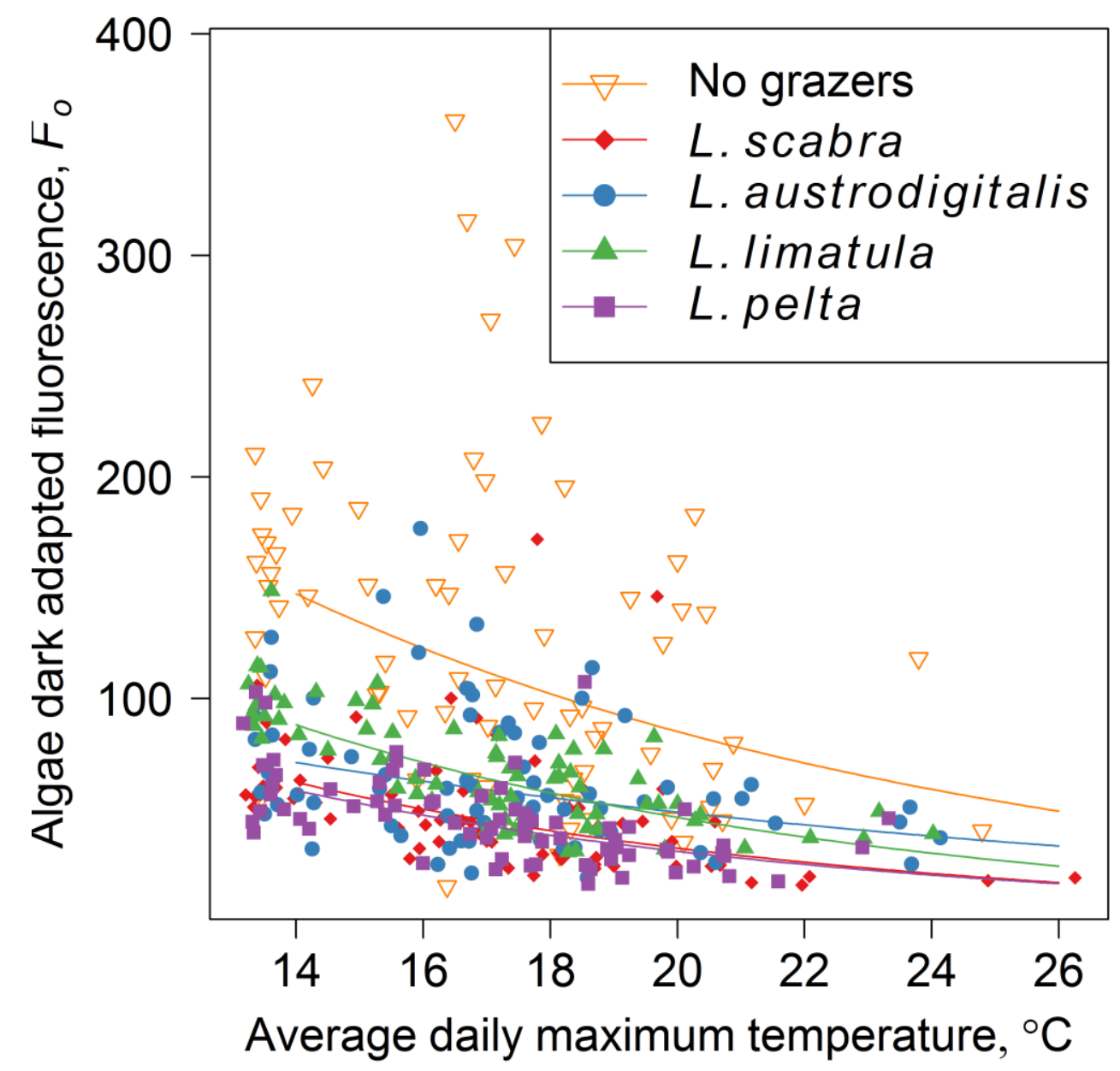

883

884 Figure 4. Algae dark adapted fluorescence, $F_{o}$ (a proxy for algal density), on experimental plates

885 versus limpet species treatment and average daily maximum temperature in the time period

886 preceding each of six census dates between June and December 2013. Fitted lines are back-

887 transformed estimates from models fitted with log-transformed $F_{o}$ values. 


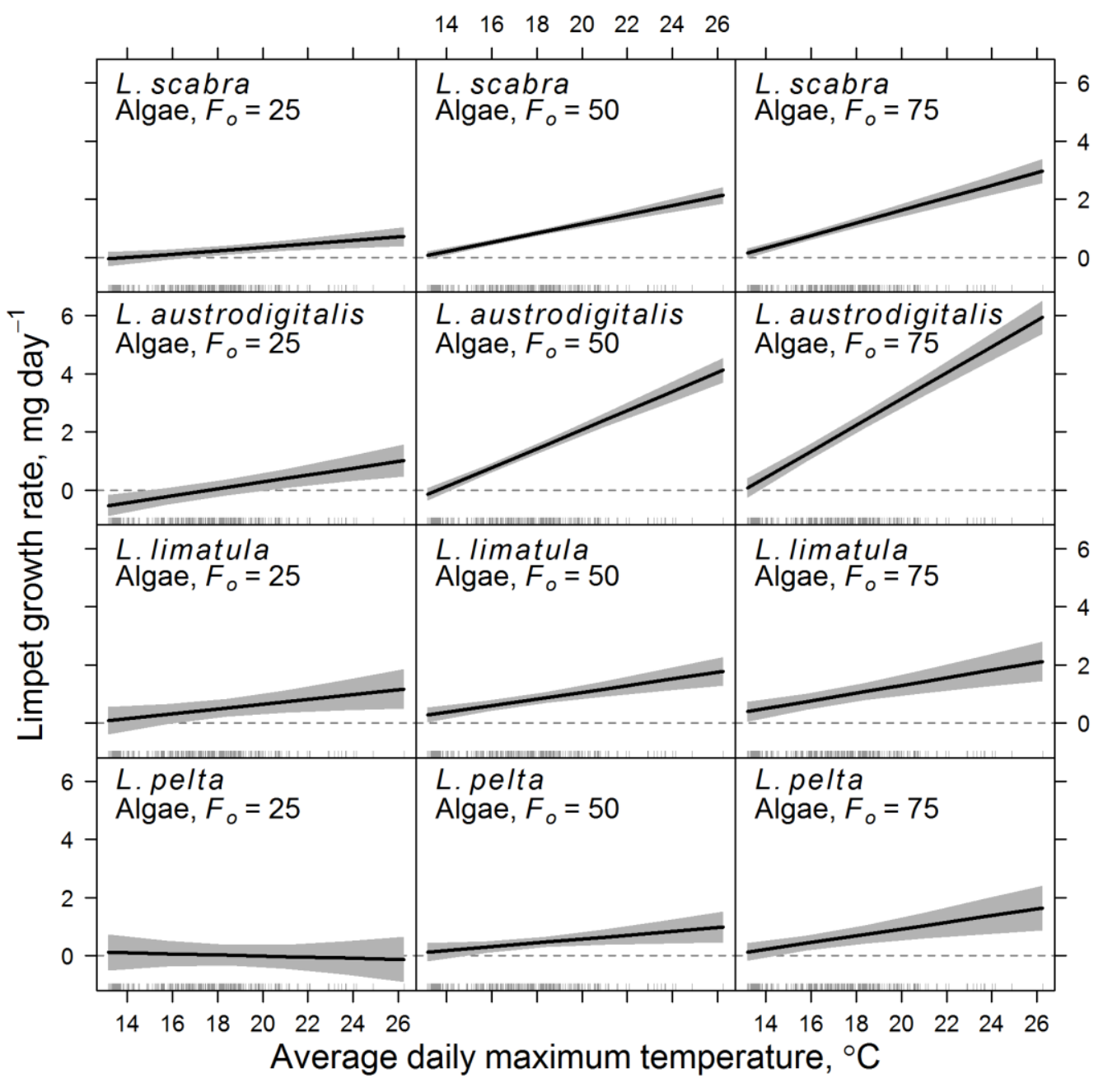

890 Figure 5. Partial regression slopes $( \pm 95 \%$ confidence limits shown in grey) from the linear

891 model of limpet growth rate versus average daily maximum temperature during a census period,

892 algal density $\left(\log F_{o}\right.$ ) at the start of a census period, and limpet species. Individual panels

893 illustrate the fitted relationship between average daily maximum temperature $\left({ }^{\circ} \mathrm{C}\right)$ and limpet

894 growth rate $\left(\mathrm{mg} \mathrm{day}^{-1}\right)$, for each limpet species (rows) at 3 representative algal density values

895 (left column, $F_{o}=25$; center, $F_{o}=50$; right column, $F_{o}=75$ ). The rug of points on the horizontal

896 axis represents the distribution of average daily maximum temperature values in the dataset. 

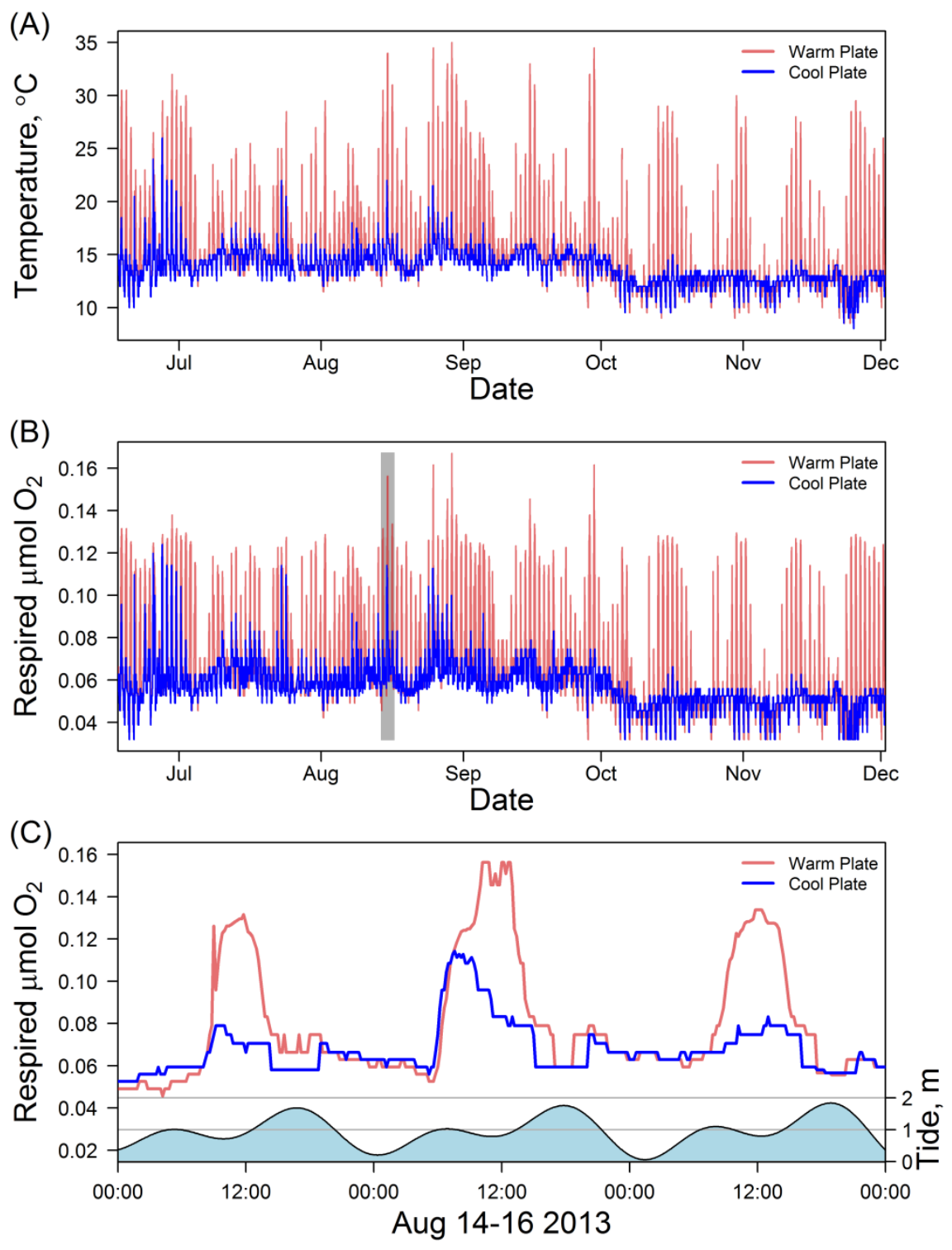

898 Figure 6. Estimated respiration rates for an average size L. scabra (18.5 mg dry tissue mass)

899 living on the single warmest (red) and single coolest (blue) plate in the field experiment. A)

900 Temperature records for the warmest and coolest plates in the field that held L. scabra. B).

901 Estimated respiration rates for L. scabra on the warmest and coolest plates. A close up view of

902 the three day time period represented by the grey box in (B) is shown in (C), along with the 903 corresponding tides. 


\section{Supplemental Tables}

906 Table S1. Dry tissue mass (mg) distributions of limpets used in the aerial and aquatic respiration

907 trials $(\mathrm{n}=12$ per species per temperature).

\begin{tabular}{lccc} 
Species & $\begin{array}{c}\text { Mean dry tissue mass, } \\
\mathrm{mg}( \pm 1 \mathrm{SD})\end{array}$ & $\begin{array}{c}\text { Minimum tissue } \\
\text { mass, } \mathrm{mg}\end{array}$ & $\begin{array}{c}\text { Maximum tissue } \\
\text { mass, mg }\end{array}$ \\
\hline L. scabra & $23.1( \pm 9)$ & 6.8 & 49.1 \\
L. austrodigitalis & $29.0( \pm 10)$ & 12.0 & 63.7 \\
L. limatula & $43.0( \pm 20)$ & 11.2 & 117.5 \\
L. pelta & $32.5( \pm 11)$ & 12.3 & 69.7
\end{tabular}

908

909 
910 Table S2. Results of generalized least squares model of log-transformed dark-adapted algal

911 fluorescence values $\left(F_{o}\right)$ versus average daily maximum temperature and limpet species

912 (including the No Grazer treatment). The model included an $\mathrm{AR}(1)$ correlation structure for the

913 Date of each reading $(\varphi=0.23)$.

914

\begin{tabular}{lcccc}
\hline & numDf & denomDF & $F$ & $P$ \\
\hline Intercept & 1 & 350 & $21,225.4$ & $<0.001$ \\
Avg. daily maximum temperature & 1 & 350 & 104.3 & $<0.001$ \\
Species & 4 & 350 & 80.8 & $<0.001$ \\
Avg. daily maximum $\times$ Species & 4 & 350 & 1.89 & 0.111
\end{tabular}

915

916 
917 Table S3. Treatment contrast coefficient estimates for the generalized least squares model of

$918 \log _{e}$-transformed dark-adapted algal fluorescence values $\left(F_{o}\right)$ versus average daily maximum

919 temperature and limpet species (including the No Grazer treatment). The No Grazer treatment is

920 the reference level.

\begin{tabular}{lcccc}
\hline Coefficient & Estimate & Std. Error & $t$-value & $P$ \\
\hline $\begin{array}{l}\text { Intercept } \\
\text { Average daily maximum }\end{array}$ & 6.422 & 0.327 & 19.73 & $<0.001$ \\
temperature & -0.100 & 0.019 & -5.32 & $<0.001$ \\
$\begin{array}{l}\text { L. scabra } \\
\text { L. austrodigitalis }\end{array}$ & -0.722 & 0.425 & -1.70 & 0.091 \\
$\begin{array}{l}\text { L. limatula } \\
\text { L. pelta }\end{array}$ & -1.402 & 0.446 & -3.15 & 0.002 \\
$\begin{array}{l}\text { Avg. daily max. } \times \\
\text { L. scabra }\end{array}$ & -0.411 & 0.442 & -0.93 & 0.353 \\
$\begin{array}{l}\text { Avg. daily max. } \times \\
\text { L. austrodigitalis }\end{array}$ & -0.746 & 0.434 & -1.72 & 0.086 \\
$\begin{array}{l}\text { Avg. daily max. } \times \\
\text { L. limatula }\end{array}$ & 0.043 & 0.024 & -0.52 & 0.607 \\
$\begin{array}{l}\text { Avg. daily max. } \times \\
\text { L. pelta }\end{array}$ & -0.010 & 0.026 & 1.67 & 0.097 \\
& & & & \\
& -0.015 & 0.026 & -0.39 & 0.698 \\
& & & -0.58 & 0.565 \\
& & & &
\end{tabular}

922

923 
924 Table S4. Coefficients for regressions of the form $Y=\alpha X^{\beta}$ for limpet dry tissue mass or shell

925 mass (mg) versus shell projected area $\left(\mathrm{mm}^{2}\right)$ when viewed from overhead. $R^{2}$ for linear fits to $\log$

926 transformed data are given, along with sample size $n$ for each species.

\begin{tabular}{lccccccc}
\cline { 2 - 6 } & \multicolumn{3}{c}{ Dry tissue mass } & \multicolumn{3}{c}{ Shell mass } & \\
\hline Species & $\alpha$ & $\beta$ & $R^{2}$ & $\alpha$ & $\beta$ & $R^{2}$ & $\mathrm{n}$ \\
\hline L. scabra & 0.0435 & 1.36 & 0.75 & 0.100 & 1.62 & 0.87 & 247 \\
L. austrodigitalis & 0.0376 & 1.41 & 0.83 & 0.132 & 1.55 & 0.80 & 242 \\
L. limatula & 0.0350 & 1.40 & 0.90 & 0.103 & 1.56 & 0.87 & 227 \\
L. pelta & 0.1100 & 1.21 & 0.85 & 0.177 & 1.46 & 0.88 & 245
\end{tabular}

927 
928 Table S5. Treatment contrast coefficient estimates for the linear mixed effects model of limpet

929 growth rate $\left(\mathrm{mg} \mathrm{day}^{-1}\right)$ with average daily maximum temperature during each census period,

$930 \log _{e}$-transformed algal density $\left(F_{o}\right)$ at the beginning of each census period, and limpet species as

931 fixed factors. The random effects included $\log _{e}$-transformed $F_{o}$, an effect for plate (standard

932 deviation of intercept $=2.23, \log \left(F_{o}\right)=0.60$ ), and for individual limpets nested within plates to

933 account for the repeated measures of limpets through time (standard deviation of intercept $=$

$9340.99, \log \left(F_{o}\right)=0.28$, residual $\left.=0.74\right)$. First order autocorrelation among the repeated limpet

935 measures through time is accounted for using an $\operatorname{AR}(1)$ autoregressive correlation structure $(\varphi=$

936 0.22). The estimate for L. scabra is the reference level in the model. The model was fit using the

937 nlme package (Pinheiro and Bates, 2000).

\begin{tabular}{lccccc}
\hline Coefficient & Estimate & Std. Error & df & $t$-value & $P$ \\
\hline Intercept & 8.865 & 2.508 & 671 & 3.535 & $<0.001$ \\
Average daily maximum temperature, ${ }^{\circ} \mathrm{C}$ & -0.847 & 0.133 & 671 & -6.382 & $<0.001$ \\
Log $\left(F_{o}\right)$ & -3.402 & 0.650 & 671 & -5.231 & $<0.001$ \\
L. austrodigitalis & -8.846 & 4.056 & 44 & -2.181 & 0.035 \\
L. limatula & -3.350 & 4.245 & 44 & -0.789 & 0.434 \\
L. pelta & -4.779 & 4.293 & 44 & -1.113 & 0.272 \\
Avg. daily max. $\times \log \left(F_{o}\right)$ & 0.300 & 0.035 & 671 & 8.684 & $<0.001$ \\
Avg. daily max. $\times$ L. austrodigitalis & 0.785 & 0.219 & 671 & 3.581 & $<0.001$ \\
Avg. daily max. $\times$ L. $\operatorname{limatula}$ & 0.435 & 0.233 & 671 & 1.868 & 0.062 \\
Avg. daily max. $\times$ L. pelta & 0.569 & 0.242 & 671 & 2.352 & 0.019 \\
Log $\left(F_{o}\right) \times$ L. austrodigitalis & 3.085 & 1.040 & 671 & 2.966 & 0.003 \\
Log $\left(F_{o}\right) \times$ L. limatula & 1.802 & 1.053 & 671 & 1.711 & 0.088 \\
Log $\left(F_{o}\right) \times$ L. pelta & 1.948 & 1.150 & 671 & 1.694 & 0.091 \\
Avg. daily max. $\times \log \left(F_{o}\right) \times$ & & & & & \\
L. austrodigitalis & -0.255 & 0.057 & 671 & -4.504 & $<0.001$ \\
Avg. daily max. $\times \log \left(F_{o}\right) \times$ L. limatula & -0.178 & 0.059 & 671 & -3.018 & 0.003 \\
Avg. daily max. $\times \log \left(F_{o}\right) \times$ L. pelta & -0.197 & 0.066 & 671 & -2.983 & 0.003
\end{tabular}

